\title{
ASPECTOS PENAIS E REGULATÓRIOS DA VENDA DE MEDICAMENTOS SEM REGISTRO
}

\section{CRIMINAL AND REGULATORY ASPECTS OF THE SALE OF PHARMACEUTICALS WITHOUT REGISTRATION}

\author{
ASPECTOS PENALES Y REGULATORIOS DE LA VENTA DE MEDICAMENTOS \\ SIN REGISTRO
}

\author{
THIAGO BOTTINO \\ http://orcid.org/0000-0003-0557-5412 / http://lattes.cnpq.br/3134056986747443 / thiago.bottino@fgv.br \\ Fundação Getúlio Vargas do Rio de Janeiro - FGV DIREITO RIO
}

Rio de Janeiro, RJ, Brasil

\begin{abstract}
AleXANDRe Ortigão SAMPaio BuARQUe SCHILler http://orcid.org/0000-0001-8558-1972 / http://lattes.cnpq.br/5672900195244400 / alexandre.schiller@gmail.com Fundação Getúlio Vargas do Rio de Janeiro - FGV DIREITO RIO
\end{abstract}

Rio de Janeiro, RJ, Brasil

\begin{abstract}
RESUMO
Este ensaio tem por objetivo tratar dos aspectos penais e regulatórios da venda de medicamentos sem registro no Brasil, tipificado no artigo 273 , § $1^{\circ}$-B, do Código Penal, pela Lei n $9.677 / 1998$, chamada "Lei dos Remédios", através de uma investigação analítica, com base numa pesquisa jurídico-teórica pelo método indutivo, da legislação e da jurisprudência dos Tribunais Superiores. Diante da controvérsia que se alonga há aproximadamente vinte anos quanto à razoabilidade do tipo penal e da sua constitucionalidade, já declarada pelos Superior Tribunal de Justiça e Supremo Tribunal Federal, a questão que se propõe, neste trabalho, é de fazer um contraponto à restrição imposta pelo legislador à produção e comercialização de medicamentos sem registro no Brasil com o entendimento adotado pelo Judiciário no que toca à necessidade de fornecimento e custeio, pelo Estado, de medicamentos que ainda não possuem registro na Anvisa. Ao final, pretende-se questionar a sobreposição do direito penal à regulação da Agência Nacional de Vigilância Sanitária.
\end{abstract}

Palavras-chave: crimes de perigo e dano; medicamentos; registro; regulação.

\begin{abstract}
The purpose of this essay is to deal with the criminal and regulatory aspects of the pharmaceuticals sale without previous registration in Brazil, as a consequence of the rule established in article 273, paragraph 1-B, of the Penal Code, by the so-called "Remedies Law", through an analytical investigation, based on a legal-theoretical research using the inductive method, of the legislation and jurisprudence of the Superior Courts. Faced with the controversy that has been going on for approximately 20 years regarding the reasonableness of the criminal type, and given the recognition of the constitutionality of this criminal law by the Superior Court of Justice and the Federal Supreme Court, this work aims to offer a counterpoint to the restriction imposed by Brazilian legislation on the production and commercialization of medicines without previous registration with the understanding adopted by the Judiciary Court regarding the possibility to the State to grant funds and supply medicines not yet registered with Anvisa. In the end, we intend to question the overlapping of criminal law to the regulation of the National Sanitary Surveillance Agency
\end{abstract}

Keywords: crimes of danger and damage; pharmaceuticals; pharmaceuticals registration; regulation. 


\section{RESUMEN}

Este ensayo tiene por objetivo tratar los aspectos penales y regulatorios de la venta de medicamentos sin registro en Brasil, tipificado en el artículo 273, § $1^{\circ}$-B, del Código Penal, por la Ley $n^{\circ}$ 9.677/1998, llamada "Ley de los Remedios", através de una investigación analítica, basado en una investigación legal-teórica usando el método inductivo, de la legislación y de la jurisprudencia de los Tribunales Superiores. Ante la controversia que se extiende hace aproximadamente veinte años en cuanto a la razonabilidad del tipo penal y de su constitucionalidad, ya declarada por los superiores Tribunal de Justicia y Supremo Tribunal Federal, la cuestión que se propone, en este trabajo, es de hacer un contrapunto a la restricción impuesta por el legislador a la producción y comercialización de medicamentos sin registro en Brasil con el entendimiento adoptado por el Judiciario en lo que se refiere a la necesidad de suministro y costeo por el Estado de medicamentos que aún no tienen registro en la Anvisa. Al final, se pretende cuestionar la superposición del derecho penal a la regulación de la Agencia Nacional de Vigilancia Sanitaria.

Palabras clave: crímenes de peligro y daño; drogas; registro; regulación.

\section{SUMÁRIO}

INTRODUÇÃO; 1. A LEI DOS REMÉDIOS E AS MODIFICAÇÕES DO CÓDIGO PENAL; 2. A LIBERAÇÃO DO FORNECIMENTO DE MEDICAMENTOS SEM REGISTRO NA ANVISA PELO PODER JUDICIÁRIO: UM CONTRAPONTO À CRIMINALIZAÇÃO ESTABELECIDA PELO § $1^{\circ}$-B DO ART. 273 DO CÓDIGO PENAL; 3.0 INDEVIDO ENQUADRAMENTO DA HIPÓTESE DO INCISO I DO \$1 ${ }^{\circ}$-B COMO UM CRIME DE PERIGO ABSTRATO; 4. O DIREITO PENAL DEVE SER O ÚLTIMO ANTÍDOTO: A REGULAÇÃO DA SAÚDE PÚBLICA COMPETE Ả AGÊNCIA REGULADORA; CONCLUSÃO; REFERÊNCIAS.

\section{INTRODUÇÃO}

Em julho de 1998, após ser revelada, pela imprensa, a existência de um mercado de venda maciça de medicamentos falsos fabricados e comercializados no País, o Poder Legislativo entendeu que havia a necessidade de recrudescer a repressão aos crimes que importassem na venda de produtos destinados a fins terapêuticos ou medicinais falsificados, adulterados ou de procedência ignorada, bem como que não contassem com a aprovação e registro junto à Agência de Vigilância Sanitária.

Para este fim foi, então, editada a Lei n 9.677/1998, denominada “Lei dos Remédios”, que alterou o Código Penal para aumentar a pena do crime de falsificação ou adulteração de medicamentos, dando nova redação ao artigo 273 do Código Penal.

Pela nova redação da lei, passou a ser crime hediondo, passível de pena de reclusão de dez a quinze anos e multa, não apenas a falsificação, corrupção, adulteração ou alteração de produto destinado a fins terapêuticos ou medicinais, incluindo as matérias-primas, os insumos farmacêuticos, os cosméticos, os saneantes e os de uso em diagnóstico, mas também uma série de condutas equiparadas, como a comercialização de produtos sem a identificação da sua procedência, em desacordo com a fórmula constante do registro e, no que mais nos interessa para este artigo, de produtos sem o prévio registro na ANVISA. 
Muitos doutrinadores sempre foram críticos à previsão inserida no Código Penal pela "Lei dos Remédios", mas os Tribunais Superiores, em especial o Supremo Tribunal Federal, têm entendido pela sua validade. Conquanto a Corte Especial do Superior Tribunal de Justiça, mais recentemente, tenha decidido pela inconstitucionalidade da pena prevista pelo legislador para, com isso, determinar a sua redução e substituição pela pena prevista no caput do artigo 33 da Lei $\mathrm{n}^{\circ} 11.343 / 2006^{1}$, ela não afastou a constitucionalidade do tipo penal, que ainda foi reafirmada pelo Supremo Tribunal Federal em julgados recentes. O Supremo tem entendido que a conduta recriminada pela lei é grave e coloca em risco o bem jurídico saúde pública, justificando, por isso, a aplicação da pena que foi estabelecida pelo legislador.

Contudo, o entendimento recente dos Tribunais Superiores, pela constitucionalidade do tipo penal que foi estabelecido pela "Lei dos Remédios", inclusive e em especial a hipótese de venda de medicamentos sem registro junto à Agência Nacional de Vigilância Sanitária, tem como contraponto a constante liberação², por decisões judiciais, da venda e da comercialização de medicamentos que não foram aprovados pela Agência, seja em razão da sua mora em analisar os pedidos de registro de medicamentos, seja em razão da ausência de outras opções de tratamento de doenças graves ou terminais, seja por se dar prevalência à recomendação médica, e até mesmo em razão da aprovação de certos medicamentos em outros países, postura essa que depõe contra os termos da Lei $n^{\circ}$ 9.677/1998 e da sua exposição de motivos, e nos leva a questionar a adoção da norma penal enquanto instrumento de proteção do bem jurídico saúde pública.

O problema que será discutido aqui, que está diretamente relacionada à venda de medicamentos sem registro, é que o próprio Judiciário tem mitigado e flexibilizado a disposição trazida ao Código Penal pela "Lei dos Remédios" ao liberar o fornecimento de substâncias medicinais ou terapêuticas sem o prévio aval da Agência Reguladora. Pretendemos mostrar, através de um estudo analítico, com base numa pesquisa jurídico-teórica pelo método indutivo, pautados em decisões proferidas pelos Tribunais Superiores em questões relacionadas a medicamentos ${ }^{3}$, que essa postura levanta dúvidas suficientes acerca da razoabilidade e da

\footnotetext{
1 BRASIL, Lei n ${ }^{\circ}$ 11.343, de 23 de agosto de 2006. Dispõe sobre o Sistema Nacional de Políticas Públicas sobre Drogas - Sisnad; prescreve medidas para prevenção do uso indevido, atenção e reinserção social de usuários e dependentes de drogas; estabelece normas para repressão à produção não autorizada e ao tráfico ilícito de drogas; define crimes e dá outras providências. In: Diário Oficial da República Federativa do Brasil, Brasília, DF, 24 ago. 2006. Disponível em http://www.planalto.gov.br/ccivil_03/_ato20042006/2006/lei/l11343.htm Acesso em 8 mai. 2018.

${ }^{2}$ Nesse sentido, v. BRASIL, Tribunal de Contas da União. Relatório de Auditoria do Tribunal de Contas da União $n^{\circ}$ 009.253/2015-7, Ministério da Saúde, de Relatoria do Ministro Bruno Dantas. Disponível em: https: // contas.tcu.gov.br/etcu/AcompanharProcesso?p1=9253\&p2=2015\&p3=7. Acesso em 20 out. 2017

${ }^{3}$ As decisões foram obtidas através de pesquisa jurisprudencial junto ao STF e ao STJ utilizando-se como parâmetro de busca o critério "legislação", com a indicação do art. 273, § $1^{\circ}$-B do Código Penal, a fim de
} 
constitucionalidade da adoção do direito penal como prima ratio para a proteção da saúde pública, o que reforça a necessidade de mudanças na interpretação e na aplicação da lei, quiçá na redação do inciso I do $\S 1^{\circ}$-B do artigo 273 do Código Penal.

O presente trabalho será dividido em quatro seções, além da introdução e conclusão. A primeira discorrerá a respeito da "Lei dos Remédios" e os aspectos penais relacionados à produção e à comercialização de medicamentos de forma irregular, abordando as críticas traçadas pela doutrina e o entendimento consolidado na jurisprudência dos Tribunais Superiores quanto à constitucionalidade do artigo $273, \S 1^{\circ}-\mathrm{B}$, do Código Penal. A segunda tratará do direito ao fornecimento de remédios sem o registro na Anvisa, fazendo um contraponto à previsão do já citado inciso I do $\S 1^{\circ}$-B. A terceira abordará o indevido enquadramento da hipótese de venda de medicamentos sem registro no tipo penal de crime de perigo abstrato. A quarta abordará o papel da Anvisa, à luz da Lei n $6.437 / 1977$, tratando do seu dever de listar as substâncias nocivas à saúde e do papel da regulação enquanto instrumento prévio necessário e prejudicial para a persecução penal. Ao final, apresentaremos as nossas conclusões sintetizando o nosso posicionamento favorável a uma interpretação mais adequada, e conforme a Constituição, da regra do inciso I do $§ 1^{\circ}$-B do citado artigo 273 do Código Penal.

\section{A “LEI DOS REMÉDIOS” E AS MODIFICAÇÕES DO CÓDIGO PENAL}

A Lei n 9.677/1998, chamada de "Lei dos Remédios", que alterou o Capítulo III do Título VIII do Código Penal para introduzir o artigo 273, caput e $\$ \$ 1^{\circ}-\mathrm{A}$ e $1^{\circ}-\mathrm{B}$, foi editada após uma sequência de escândalos, em âmbito nacional, envolvendo a falsificação de remédios no Brasil. Foram vários os casos noticiados na imprensa de adulteração ou falsificação de medicamentos, a exemplo dos antibióticos Trioxina, Triaxin e Cefoxitina, e de remédios usados no combate ao câncer, como Granulokine e Androcur, em alguns casos implicando na morte de pacientes ${ }^{4-5}$.

encontrar precedentes que tratem especificamente da aplicação deste dispositivo. Foram encontrados, até 31 de outubro de 2017, 30 (trinta) precedentes junto ao STF e 134 (cento e trinta e quatro) junto ao STJ, a partir desse critério, tendo sido escolhidos alguns casos, por amostragem, para compor o exame analítico que será realizado ao longo do trabalho.

${ }^{4}$ V. Reportagem da Folha de São Paulo intitulada "Falsificar remédios vira crime hediondo", datada de 9 de maio de 1998 e disponível em http://www1.folha.uol.com.br/fsp/cotidian/ff13089830.htm. Acesso em 8 mai. 2018.

${ }^{5}$ Reportagens OGlobo intituladas "Morre bebê que tomou remédio falso" e "Estado tem 39 remédios falsificados", datadas de 8 de maio de 1998 e 9 de agosto de 1998. 
A despeito da gravidade de diversos episódios, um dos casos socialmente mais marcantes foi aquele envolvendo a empresa Schering do Brasil, que comercializou sete lotes de um medicamento anticoncepcional chamado Microvlar cujo conteúdo era totalmente ineficaz, um verdadeiro placebo. A empresa adquiriu um novo maquinário destinado à embalagem de medicamentos da sua linha de produção e, enquanto o equipamento estava em testes, foram produzidos diversos lotes de Microvlar não destinados ao consumo, verdadeiros placebos que continham uma composição da mesma cor, peso e diâmetro do medicamento original, mas sem o princípio ativo que o tornaria eficaz para evitar a concepção. Embora supostamente os medicamentos tenham sido separados para eliminação, uma parte deles acabou sendo levada à comercialização $0^{6}$, resultando daí que, após a sua ingestão, diversas mulheres acabaram por engravidar.

O caso ocasionou uma grande comoção popular ${ }^{7}$. Ele foi objeto de ação penal proposta pelo Ministério Público (processo penal $n^{\circ} 487 / 98$ ), julgada pela $2^{\text {a }}$ Vara Criminal de São Paulo em julho de 2000, da qual resultou a condenação, em primeira instância, dos diretores industrial e presidente da empresa, às penas de dois anos e quatro meses de prisão, bem como à prestação de serviço à comunidade e ao pagamento de multa. A condenação foi motivada principalmente pelo fato de que a empresa não informou aos seus consumidores após saber do equívoco na comercialização de "placebos", conforme constou da sentença. Em segunda instância a condenação foi substituída para oito meses de detenção, com a condenação ao pagamento de treze dias-multa, fixados no valor de três salários-mínimos cada ${ }^{8}$.

Como sucedâneo desses escândalos, em especial do caso da Schering, foi editado o Projeto de Lei $n^{\circ} 4.207 / 1998$, de autoria do Deputado Benedito Domingos, voltado a alterar o Código Penal e endurecer as penas dos crimes que estivessem relacionados à comercialização de produtos medicinais, supostamente com vistas a proteger a saúde pública. Foi isto, inclusive, o que constou da exposição de motivos do referido Projeto de Lei, que deu origem à nova redação do artigo 273 do Código Penal:

A incidência da ação de fraudadores inescrupulosos, ávidos de enriquecimento ilícito, ainda que à custa da disseminação de substancias nocivas, e até danosas, à

\footnotetext{
${ }^{6}$ Sentença proferida no Processo $n^{\circ} 487 / 1998$, proferida pela $2^{\text {a }}$ Vara Criminal Central de São Paulo em 21 de julho de 2000, pelo Juiz Francisco Olavo Guimarães Peret Filho. In Revista de Direito do Consumidor, vol. 37/2001. p. 363/370. jan/mar de 2001.

7 GUIMARÃES, Luís Paulo Cotrim. Penas descalibradas e leis nascidas do casuísmo exigem malabarismo de juízes. Revista Consultor Jurídico. 2014.

8 BRASIL, Tribunal de Justiça de São Paulo. Ementa do acórdão de $n^{\circ}$ 9140356-92.2000.8.26.0000 (993.00.099021-0).
} 
saúde, hoje, vem ocorrendo com frequência, explorando a boa fé pública, com a falsificação de medicamentos, em sua maioria, auto- usáveis pelo povo.

(...)

Entendemos que delitos como esses causam enormes danos à sociedade e também à economia popular, pois que atingem as classes menos favorecidas que buscam no preço mais barato, e na alternativa da auto-medicação, sem prescrição médica, à solução paliativa de seus males físicos, devendo ser, portanto, também o delito de falsificação de medicamentos classificado como crime considerado hediondo e seu agente sujeito as restrições e as insuscetibilidades alinhadas no artigo $2^{\circ} \mathrm{e}$ seus parágrafos, da lei ora modificada no presente Projeto de Lei. ${ }^{9}$

Por sua vez, o Projeto de Lei $n^{\circ} 4.535 / 1998$, de autoria do Deputado Augusto Nardes, que deu azo à Lei $n^{\circ}$ 9.695/98 e incluiu os crimes de corrupção, adulteração ou falsificação de substâncias alimentícias ou medicinais no rol de crimes hediondos, teve a seguinte justificação na sua exposição de motivos:

Nossa população tem assistido perplexa a uma sequência de mortes ocorridas em virtude da falsificação de remédios, alguns deles ministrados a portadores de doenças graves, como o câncer.

Estamos diante de crimes hediondos, perpetrados contra vítimas indefesas, incapazes de se prevenir e de se defender dessa covardia perversa.

É urgente uma modificação da lei, a fim de se dar tratamento penal compatível com a gravidade desses fatos. ${ }^{10}$

O Código Penal previa no seu artigo $272^{11}$, a punição do ato de "corromper, adulterar ou falsificar substância alimentícia ou medicinal destinada a consumo, tornando-a nociva à saúde", cominando uma pena de dois a seis anos de reclusão, além de multa. De acordo com aquela redação, para que houvesse a condenação era necessário que o produto colocasse em risco, concretamente, a saúde dos consumidores. Vale conferir as lições de Miguel Reale Junior:

Fundamental é, pois, que se comprove haver, no caso concreto, acontecido, efetivamente, o surgimento de uma situação perigosa, em função daquela conduta, que tenha posto em risco a saúde de um número indefinido de pessoas. Segundo dizeres do art. 272 do CP (LGL 1940), a ação típica pode ocorrer pelas formas de corromper, adulterar ou falsificar substância alimentícia ou medicinal destinada a consumo, tornando-a nociva à saúde ${ }^{12}$.

\footnotetext{
${ }^{9}$ BRASIL, Decreto n 2.848 , de 7 de dezembro de 1940. Institui o Código Penal. In: Diário Oficial da República Federativa do Brasil, Brasília, DF, 31 dez. 1940. Disponível em http://www.planalto.gov.br, artigo 273. Acesso em 8 mai. 2018.

10 Brasil, Projeto de Lei $n^{\circ} 4535$, de 21 de maio de 1998 . Disponível em: http://www.camara.gov.br/proposicoesWeb/fichadetramitacao?idProposicao=25675. Acesso em 25 out. 2017.

11 BRASIL, Decreto $n^{\circ}$ 2.848, de 7 de dezembro de 1940. Institui o Código Penal. In: Diário Oficial da República Federativa do Brasil, Brasília, DF, 31 dez. 1940. Disponível em http://www.planalto.gov.br, artigo 272. Acesso em 8 mai. 2018.

${ }^{12}$ REALE JUNIOR, Miguel. A inconstitucionalidade da lei dos remédios. RT. São Paulo. a. 88. v. 763. p. 415, maio 1999.
} 
Ainda sob a ótica da antiga redação do Código Penal, agora à luz do artigo $273^{13}$, aquele que alterasse "substância alimentícia ou medicinal, modificando-lhe a qualidade ou reduzindo-lhe o valor nutritivo ou terapêutico", ou suprimisse "total ou parcialmente, qualquer elemento de sua composição normal, ou substituindo-o por outro de qualidade inferior", ficaria sujeito à pena de reclusão de um a três anos. Na mesma pena incorreria quem vendesse, expusesse à venda, mantivesse em depósito para venda ou, sob qualquer forma, entregasse a consumo a substância adulterada ou falsificada.

A regra do artigo 273 tratava de hipótese de "nocividade negativa", para pegar emprestada a expressão de Heleno Fragoso ${ }^{14}$. O prejuízo à saúde decorria de uma conduta indireta, que privasse o consumidor dos benefícios nutritivos ou terapêuticos próprios da substância medicinal. Também nesse caso era necessário que houvesse a comprovação da nocividade, tratando-se de uma hipótese de crime de perigo concreto, ou seja, em que havia a efetiva comprovação do potencial de dano.

Com a nova disposição legal trazida pela "Lei dos Remédios", contudo, deixou o crime de depender da comprovação do prejuízo ao consumidor, passando a se tratar de um crime de perigo abstrato, em que a simples prática do ato tipificado na lei, independentemente de qualquer comprovação de prejuízo, deve resultar na aplicação da pena. 0 artigo 272 , que dispunha sobre a matéria, passou a tratar exclusivamente de crimes relacionados a substâncias ou produtos alimentícios destinados ao consumo. A hipótese dos medicamentos ganhou nova abordagem, específica, no artigo 273, caput e parágrafos, do Código Penal, que passou a prever o seguinte:

Art. 273 - Falsificar, corromper, adulterar ou alterar produto destinado a fins terapêuticos ou medicinais:

Pena - reclusão, de 10 (dez) a 15 (quinze) anos, e multa.

$\S 1^{\circ}$ - Nas mesmas penas incorre quem importa, vende, expõe à venda, tem em depósito para vender ou, de qualquer forma, distribui ou entrega a consumo o produto falsificado, corrompido, adulterado ou alterado.

$\S 1^{\circ}$-A - Incluem-se entre os produtos a que se refere este artigo os medicamentos, as matérias-primas, os insumos farmacêuticos, os cosméticos, os saneantes e os de uso em diagnóstico.

$\S 1^{\circ}$-B. Está sujeito às penas deste artigo quem pratica as ações previstas no $\S 1^{\circ}$ em relação a produtos em qualquer das seguintes condições:

I- sem registro, quando exigível, no órgão de vigilância sanitária competente;

II- em desacordo com a fórmula constante do registro previsto no inciso anterior;

III- sem as características de identificações e qualidades admitidas para a comercialização;

IV- com redução de seu valor terapêutico ou de sua atividade;

V- de procedência ignorada;

13 BRASIL, Decreto $n^{\circ} 2.848$, de 7 de dezembro de 1940. Institui o Código Penal. In: Diário Oficial da República Federativa do Brasil, Brasília, DF, 31 dez. 1940. Disponível em http://www.planalto.gov.br, artigo 273. Acesso em 8 mai. 2018.

${ }^{14}$ FRAGOSO, Heleno. Lições de Direito Penal, São Paulo: José Bushatsky Editor, 1959, v. 3, p. 701. 
VI- adquiridos de estabelecimento sem licença da autoridade sanitária competente.

De acordo com a nova redação, além de ser crime adulterar, falsificar e comercializar um produto medicinal e seus congêneres - inclusive produtos medicinais, terapêuticos, matériasprimas, insumos farmacêuticos, cosméticos, saneantes e de uso em diagnóstico -, a comercialização desses produtos sem o prévio registro na Anvisa passou a implicar na igual subsunção à norma penal. Da mesma forma, a revenda daqueles produtos, se adquiridos de estabelecimento sem licença ou com a sua procedência ignorada passou a atrair a aplicação do tipo penal.

As disposições dos $\S \S 1^{\circ}$-A e $1^{\circ}$-B deixam claro que o legislador ampliou as hipóteses de sujeição à norma penal, alterando substancialmente o tipo antes previsto pela lei, de forma a alcançar o que antes eram meros ilícitos administrativos, é dizer, irregularidades que estavam sujeitas ao controle, fiscalização e punição em sede administrativa, ex vi o disposto na Lei $n^{\circ}$ $6.437 / 1977^{15}$. Em outras palavras, a hipótese de subsunção à norma penal foi exponencialmente ampliada e as consequências para o que antes eram irregularidades administrativas passou a ser o encarceramento, com a aplicação de uma pena superior à do homicídio.

Decorre daí que a comercialização de um remédio não registrado na Anvisa, ainda que não seja nocivo à saúde, passou a constituir crime. Pela redação que foi dada pelo legislador, haverá a subsunção à esfera penal ainda que o remédio já tenha sido aprovado e comercializado há anos no exterior, com a comprovação científica de que produz os efeitos desejados ou que não gera danos à saúde maiores do que os benefícios proporcionados, não constituindo, portanto, um risco para a saúde pública. Passou a ser crime, também, a venda de anabolizantes e suplementos alimentares estrangeiros sem registro na Agência, ainda que o seu conteúdo seja similar ou mesmo idêntico a outros produtos produzidos no Brasil. Também nessa hipótese a lei impõe a condenação, ainda que não haja qualquer prova de nocividade ou perigo à saúde pública. Bastará, também, para a subsunção ao tipo penal, que falte a comprovação da procedência do produto ou mesmo que ele tenha sido adquirido de um estabelecimento que esteja sem o respectivo registro perante a Agência Nacional de Vigilância Sanitária. As hipóteses, portanto, são variadas e independem de comprovação de qualquer prejuízo, seja potencial ou efetivo.

15 BRASIL, Lei $n^{\circ}$ 6.437, de 20 de agosto de 1977. Configura infrações à legislação sanitária federal e estabelece as sanções respectivas, e dá outras providências. In: Diário Oficial da República Federativa do Brasil, Brasília, DF, 24 ago. $1977 . \quad$ Disponível em http://www.planalto.gov.br/ccivil_03/leis/l6437.htm?TSPD_101_R0=1c6de2098e2f3f605c0957c2f3aa1a71c 5C0000000000000000ae8a3cbdffff00000000000000000000000000005af11f6b00ef33db7e Acesso em 8 mai. 2018. 
Em razão da amplitude da norma penal, a doutrina passou a tecer severas críticas à novel redação dada pela "Lei dos Remédios", criticando que a norma foi oportunista e precipitada, voltada a responder a uma pressão momentânea, ampliada especialmente pela mídia ${ }^{16-17}$. Como um reflexo disso, e diante da aplicação da norma penal tal qual ela foi prevista pelo legislador, os tribunais se viram obrigados a enfrentar a constitucionalidade e a razoabilidade da nova regra penal introduzida no ordenamento jurídico pelo legislador.

Miguel Reale Junior, por exemplo, apontou a inconstitucionalidade das modificações trazidas pela “Lei dos Remédios”, afirmando que os incisos do § 1-B do artigo 273 do Código Penal, à exceção do inciso IV, que trata da criminalização da redução do valor terapêutico ou da atividade do remédio, estão maculados de incontornável inconstitucionalidade. Pontuou, ainda, que o inciso IV do $\S 1^{\circ}$-B e o caput do $\S 1^{\circ}$-A só seriam admissíveis se recebessem interpretação conforme à Constituição para torná-los crimes de ameaça concreta, exigindo-se a prova do real risco à saúde pública:

A inconstitucionalidade por lesão aos valores e princípios constitucionais é patente, dada a extensão da desmedida promovida pela novel normativa penal. Isto posto, posso, com segurança, alcançar as seguintes conclusões, que exponho de forma articulada para a melhor visualização da matéria:

a) as normas contidas na Lei 9.677 de 1998 , no que tange à tipificação de crimes contra a saúde pública, nem sempre guardam adequada relação com o bem jurídico constitucionalmente tutelado, qual seja, a saúde pública;

b) as novas regras atingem, em seu conjunto, os princípios constitucionais da proporcionalidade e da ofensividade;

c) a normativa do art. 273 , caput, $\$ 1 .^{\circ}-\mathrm{B}, \mathrm{I}$, II, III, V e VI, padece de incontornável inconstitucionalidade, uma vez que os fatos incriminados ou c.1) não são de molde a ameaçar, colocar em risco ou lesar interesses relevantes, ou c.2) ferem, frontalmente, os princípios constitucionais fundamentais da proporcionalidade e da ofensividade, atingindo os valores supremos da liberdade e da justiça;

d) as regras do art. 273 , caput, parágrafo primeiro e $\$ 10^{\circ}$-A, e o inc. IV do $\S 1 .^{\circ}-B$, embora firam os mesmos princípios, se consideradas por si só e em exegese literal, podem ser salvas se receberem interpretação que as conforme à Constituição. Para tanto, os crimes aí tipificados devem ser tidos como crimes de perigo concreto, dependendo, portanto, para a sua efetiva configuração, da comprovação de risco real à saúde pública, em razão da nocividade negativa, ou seja, da perda ou redução significativa dos predicados do produto ${ }^{18}$.

\footnotetext{
${ }^{16}$ KOERNER, Andrei. Desordem Legislativa, Distribuição de Poder e Desigualdade Social - Reflexões a Propósito da Lei $\mathrm{n}^{\circ} \mathbf{9 . 6 7 7}$, de 2 de Julho de 1998. INSTITUTO BRASILEIRO DE CIÊNCIAS CRIMINAIS - IBCCRIM, Boletim $\mathrm{n}^{\circ} 71$, de Outubro de 1998.

${ }^{17}$ FARIA, Antônio Celso Campos de Oliveira. A vulgarização do crime hediondo. IBCCRIM. Boletim n 71, de Outubro de 1998.

${ }^{18}$ REALE JUNIOR, Miguel. A inconstitucionalidade da lei dos remédios. RT. São Paulo. a. 88. v. 763. p. 415, maio 1999.
} 
Luiz Regis Prado, conquanto não tenha apontado a inconstitucionalidade da norma como um todo, questionou não apenas a desproporcionalidade da pena, como também a técnica legislativa adotada pelo Congresso, em razão da excessiva abrangência da norma:

Aqui, facilmente é vislumbrada a deficiência da técnica legislativa, pois foram equiparados medicamentos, cosméticos e saneantes. De fato, "não há como equiparar, na sua ofensibilidade à saúde pública, produtos destinados a fins terapêuticos ou medicinais a meros cosméticos, ou seja, a produtos que servem ao embelezamento ou à preservação da beleza ou a simples saneantes, produtos dirigidos à higienização ou à desinfecção ambiental. São tais produtos qualitativamente autônomos e não suportam uma igualdade conceituai, nem devem receber, por isso, o mesmo tratamento punitivo" (Franco, A. S. Há produto novo na praça. Boi JBCCrim, 70,1998, p. 5. Nesse sentido, Reale Jr., M. A inconstitucionalidade da lei dos remédios. JRT, 763, p. 421 ess,; Delmanto, C. Código Penal comentado, p. 496). (...)É por isso que a elaboração feita pelo legislador infraconstitucional vem sendo devidamente criticada: desrespeitaramse princípios constitucionais, quais sejam o da subsidiariedade e o da proporcionalidade $^{19}$.

Guilherme de Souza Nucci, por sua vez, já escreveu sobre a desproporcionalidade da pena para as hipóteses elencadas no artigo 273 do Código Penal, asseverando que, no seu entendimento, vender um remédio sem registro no órgão de vigilância sanitária não pode ser comparado a graves delitos de dano, a exemplo do homicídio:

É inviável acolher como razoável a pena mínima de dez anos de reclusão, em regime inicial fechado, considerado crime hediondo, para condutas de perigo, quando nem mesmo potencial concreto de dano se exige. Vender um remédio sem registro no órgão de vigilância sanitária não tem, minimamente, o padrão necessário para se comparar graves delitos de dano, como, por exemplo, o homicídio. No entanto, a pena mínima do homicídio simples é de seis anos de reclusão, enquanto a mínima do crime contra a saúde pública atinge dez anos de reclusão. Nesse prisma, a inconstitucionalidade, por afronta direta ao princípio da proporcionalidade, bem como, indiretamente, a intervenção mínima, é patente ${ }^{20}$.

No mesmo sentido, Elisa Gattás Fernandes do Nascimento, sustenta a falta de razoabilidade na pena cominada pelo legislador:

Com efeito, a pena mínima cominada ao crime do art. $273, \S 1 .{ }^{\circ}-\mathrm{B}$ e seus incisos, excede em mais de três vezes a pena máxima do homicídio culposo (art. 121, § $3{ }^{\circ}$ ), quase duas vezes a pena mínima do homicídio doloso simples (art. 121, caput), é igual à pena máxima do aborto provocado sem consentimento da gestante (art. 125), além de corresponder a cinco vezes a pena mínima da lesão corporal de natureza grave (art. 129, § $\left.2 .^{\circ}\right)$.

${ }_{19}$ PRADO, Luiz Regis. Curso de Direito Penal Brasileiro. Volume 3. Parte Especial. 6a Edição. São Paulo: Revista dos Tribunais. 2010. p. 139/140.

${ }^{20} \mathrm{NUCCl}$, Guilherme de Souza. Manual de Direito Penal. $7^{\text {a }}$ edição. São Paulo: Revista dos Tribunais. p. 944 
Assim, sob tal ponto de vista, a nova redação do art. 273 colocou em pé de igualdade condutas absolutamente distintas do ponto de vista da lesividade, igualando situações possivelmente inigualáveis do ponto de vista jurídico-penal ${ }^{21}$.

A despeito das críticas, o Supremo Tribunal Federal vem afirmando a constitucionalidade do tipo penal estabelecido pelo legislador através do art. 273, caput e parágrafos. Com efeito, em outubro de 2016, a $2^{\text {a }}$ Turma do Supremo Tribunal Federal, ao julgar o Agravo Regimental interposto no Recurso Extraordinário de n 971.187/SP, sob o voto do Min. Teori Zavascki, reafirmou a jurisprudência da Corte no sentido da constitucionalidade do artigo 273 do Código Penal, inclusive do seu $\$ 1^{\circ}-\mathrm{B}$, afirmando que já há precedentes de ambas as Turmas da Corte que afastam a tese de que o art. 273 seria incompatível com a Constituição da República ${ }^{22}$.

Embora a questão ainda não tenha sido submetida ao Tribunal Pleno, o STF tem entendido que não compete ao Judiciário rever as penas estabelecias pelo legislador, rejeitando, inclusive, a tese, amplamente sustentada pela doutrina, da inconstitucionalidade do preceito secundário da norma, referente à pena de dez a quinze anos de prisão. É o que se pode ver do acórdão do Agravo Regimental no Recurso Extraordinário n 829.226/SP, de Relatoria do Min. Luiz Fux, julgado em fevereiro de 2015, no qual entendeu o Ministro que "o Poder Judiciário não detém competência para interferir nas opções feitas pelo Poder Legislativo a respeito da apenação mais severa daqueles que praticam condutas elencadas em norma penal incriminadora". Citando um precedente anterior, concluiu que "cuida-se de opção político-legislativa na apenação com maior severidade aos sujeitos ativos das condutas elencadas na norma penal incriminadora e, consequentemente, falece competência ao Poder Judiciário interferir nas escolhas feitas pelo Poder Legislativo na edição da referida norma"23.

O Superior Tribunal de Justiça, por sua vez, a partir do julgamento, pela Corte Especial, em fevereiro de 2015, da Arguição de Inconstitucionalidade no Habeas Corpus n 239.363/PR, passou a entender que haveria a inconstitucionalidade da pena cominada à conduta prevista no artigo 273 , § $1^{\circ}-B$, do Código Penal, mas que nenhuma ilegalidade haveria no tipo penal. Ao julgar o caso, Ministro Sebastião Reis Júnior, Relator, ponderou que "se comparado com o crime de tráfico de drogas — notoriamente mais grave e cujo bem jurídico também é a saúde pública —,

${ }^{21}$ NASCIMENTO, Elisa Gattás Fernandes do. Contrafação de Medicamentos: uma análise sob a ótica da saúde pública. Ciências Penais | vol. 15/2011 | p. 105 - 132 | Jul - Dez / 2011. DTR\2011\5213

${ }^{22}$ BRASIL. Supremo Tribunal Federal, RE n 971187 AgR, Relator Min. Teori Zavascki, Segunda Turma, julgado em 07/10/2016, DJe-228 Public 26/10/2016 Disponível em http: / / portal.stf.jus.br/processos/downloadPeca. asp?id=310595879\&ext=.pdf Acesso em 8 mai. 2018.

${ }^{23}$ BRASIL. Supremo Tribunal Federal, RE no 829226 AgR, Relator Min. Luiz Fux, Primeira Turma, julgado em 10/02/2015, DJe-043 Public 06/03/2015, Disponível em http://portal.stf.jus.br/processos/downloadTexto.asp?id=3745332\&ext=RTF Acesso em 8 mai. 2018. 
percebe-se a total falta de razoabilidade do preceito secundário do art. 273 , $\S 1^{\circ}-\mathrm{B}$, do Código Penal, sobretudo após a edição da Lei n. $11.343 / 2006^{24}$, que, apesar de haver aumentado a pena mínima de 3 para 5 anos, introduziu a possibilidade de redução da reprimenda, quando aplicável o § 40 do art. 33, de $1 / 6$ a 2/3"25. Concluiu o Ministro:

Mostra-se, em meu entender, ser imprescindível a atuação do Judiciário para corrigir o exagero e ajustar a pena cominada à conduta de ter em depósito para vender 9 frascos de estanozolol e 25 comprimidos de oximetolona, medicamentos de procedência ignorada, isso em atenção ao princípio constitucional da proporcionalidade.

Assim, a controvérsia instaurada nas Cortes Superiores diz respeito à constitucionalidade do prazo, mas não à aplicação do tipo penal. Nem o Supremo Tribunal Federal, nem o Superior Tribunal de Justiça afastaram a aplicação da hipótese prevista no $\S 1^{\circ}$-B do artigo 273 , que continua vigente para impor a punição contra os fatos ali enquadrados.

Curiosamente, porém, o próprio Judiciário autoriza a venda e fornecimento de remédios que não estão registrados ou que não foram aprovados pela Agência Nacional de Vigilância Sanitária, independentemente de manifestação da Anvisa nos respectivos autos judiciais. Tanto assim é que há hoje em curso no Supremo Tribunal Federal uma discussão extremamente relevante tanto do ponto de vista econômico, quanto dos pontos de vista social e regulatório, sobre a possibilidade de o Sistema Único de Saúde (SUS) custear tratamentos que dependem de drogas que não são autorizadas pela Anvisa ou que não são fabricadas no País. Discute a Corte, inclusive, se deve o Judiciário liberar a venda de medicamentos que não foram registradas junto à Agência Nacional de Vigilância Sanitária.

Essa discussão, como veremos adiante, traz um forte contraponto à regra estabelecida no $\S 1^{\circ}$-B do artigo 273 do Código Penal, na medida em que a contumaz liberação, por força de comando judicial, do fornecimento de substâncias medicinais e terapêuticas não autorizadas pela Anvisa, suscita dúvidas quanto à legitimidade e mesmo à adequação da atual interpretação

\footnotetext{
${ }^{24}$ BRASIL, Lei $n^{\circ} 11.343$, de 23 de agosto de 2006. Dispõe sobre o Sistema Nacional de Políticas Públicas sobre Drogas - Sisnad; prescreve medidas para prevenção do uso indevido, atenção e reinserção social de usuários e dependentes de drogas; estabelece normas para repressão à produção não autorizada e ao tráfico ilícito de drogas; define crimes e dá outras providências. In: Diário Oficial da República Federativa do Brasil, Brasília, DF, 24 ago. 2006. Disponível em http://www.planalto.gov.br/ccivil_03/_ato20042006/2006/lei/l11343.htm Acesso em 8 mai. 2018.

${ }^{25}$ BRASIL. Superior Tribunal de Justiça, HC 239.363/PR, Rel. Ministro SEBASTIÃO REIS JÚNIOR, SEXTA TURMA, julgado em 19/11/2012, DJe 18/12/2012, disponível em https: / / ww2.stj.jus.br/processo/revista/inteiroteor/?num_registro $=201200764901 \& d t \_p u b l i c a c a o=18 / 12 /$ $\underline{2012}$ Acesso em 8 mai. 2018.
} 


\section{A LIBERAÇÃO DO FORNECIMENTO DE MEDICAMENTOS SEM REGISTRO NA ANVISA PELO PODER JUDICIÁRIO: UM CONTRAPONTO À CRIMINALIZAÇÃO ESTABELECIDA PELO \$ $1^{\circ}$-B DO ART. 273 DO CÓDIGO PENAL.}

Diversos levantamentos do Conselho Nacional de Justiça e do Tribunal de Contas da União realizados nos últimos anos dão conta da distribuição de uma média de 150.000 processos por ano nos tribunais federais e estaduais para discutir matérias relacionadas à saúde pública, dos quais $85 \%$ estão relacionados a demandas voltadas ao fornecimento de medicamentos ${ }^{26}$. Apenas nos anos de 2013 e 2014 foram distribuídas aproximadamente 18.000 ações perante a Justiça Federal e 100.000 ações nos Tribunais de São Paulo, Rio Grande do Sul e Minas Gerais, tudo consoante constou do acórdão da Auditoria do Tribunal de Contas da União de nº 009.253/2015$7^{27}$. Uma constatação que se pode fazer a partir desse levantamento é particularmente relevante para o tema deste artigo: a judicialização constante do direito de fornecimento de medicamentos que não possuem registro na Anvisa. Veja-se trecho da referida decisão:

103. Na União, observou-se o seguinte perfil: a) o número de ações judiciais federais é crescente e sua proporção por habitante é maior em estados das regiões Sul, Centro-Oeste e Sudeste; e b) os gastos federais com a judicialização são crescentes e concentram-se em três medicamentos que não fazem parte da RENAME, sendo que um deles não possui registro na Anvisa (capítulo 4).

(...)

169. A maior parte dos gastos com medicamentos judicializados do Ministério da Saúde diz respeito a itens não incorporados ao SUS, sendo que uma parcela significativa desses itens diz respeito a itens que não foram registrados pela Agência Nacional de Vigilância Sanitária (Anvisa). Em relação às secretarias de saúde, também encontrou-se um grande valor despendido em itens não incorporados pelos SUS e/ou sem registro na Anvisa.

170. Devido às limitações financeiras, o fornecimento de bens e serviços pelo Estado deve ser racionalizado com base em princípios e critérios de priorização. No caso do SUS, o princípio da integralidade da assistência consiste na dispensação de medicamentos e produtos de interesse para a saúde, cuja prescrição esteja em conformidade com as diretrizes terapêuticas definidas em protocolo clínico para a doença ou agravo à saúde a ser tratado, ou com base nas relações de medicamentos instituídas pelo gestor federal do SUS ou, de forma suplementar, pelos gestores estaduais e municipais do SUS (arts. 19-M e 19-P da Lei 8.080/1990, incluídos pela Lei 12.401/2011).

171. No âmbito da judicialização da saúde, segundo Schulze e Chiarelli, o Poder

26 BRASIL, Tribunal de Contas da União. Relatório de Auditoria do Tribunal de Contas da União ${ }^{\circ}$ 009.253/2015-7, Ministério da Saúde, de Relatoria do Ministro Bruno Dantas. Disponível em: https:// contas.tcu.gov.br/etcu/AcompanharProcesso?p1=9253\&p2=2015\&p3=7. Acesso em 20 out. 2017. 27 Idem. 
Judiciário brasileiro tende a desconsiderar as limitações financeiras e apegar-se aos postulados da teoria dos direitos fundamentais ( 0 princípio da integralidade na saúde e sua compatibilidade com a escassez de recursos. Brasília/Revista do Centro de Estudos Judiciários, Ano XVIII, n. 64, set/dez 2014, p. 21).

(...)

199. Em conclusão, um medicamento sem registro na Anvisa e dois medicamentos que não constam das relações do SUS foram responsáveis por mais da metade dos gastos contabilizados pelo Ministério da Saúde de 2010 a 2015 com a judicialização da saúde ${ }^{28}$.

Conforme constatou o Tribunal de Contas, o Judiciário tende a acatar os pedidos para obrigar o Estado a fornecer medicamentos que não se encontram registrados perante a Agência Reguladora, ordenando o seu fornecimento em milhares de litígios que, conquanto individuais, representam um volume considerável tanto em quantidade quanto em valores, impactando no orçamento do Ministério da Saúde. De acordo com o que foi apurado pelo Tribunal de Contas da União, a repercussão no orçamento e nas despesas públicas está na casa dos bilhões de reais ${ }^{29}$.

Foi justamente por conta da crescente judicialização que, em novembro de 2011, o mesmo Supremo Tribunal Federal que entende pela constitucionalidade da regra do $\S 1^{\circ}$ - $\mathrm{B}$ do art. 273 do Código Penal, reconheceu a Repercussão Geral da matéria diretamente relacionada ao custeio de remédios não registrados na Anvisa, objeto de discussão no Recurso Extraordinário $\mathrm{n}^{\circ}$ 657.718/MG, de Relatoria do Ministro Marco Aurélio Mello ${ }^{30}$. O foco da discussão travada no Supremo e que ainda está em curso sem uma decisão final da Corte diz respeito justamente à possibilidade de o Judiciário impor à União, Estados e Municípios, o fornecimento de um medicamento não registrado perante a Agência Reguladora. O voto do Ministro Relator do caso foi no sentido de que "não sendo o caso de industrialização ou comercialização no território brasileiro, e sim de importação excepcional para uso próprio, individualizado, cumpre ao Estado viabilizar a aquisição"31.

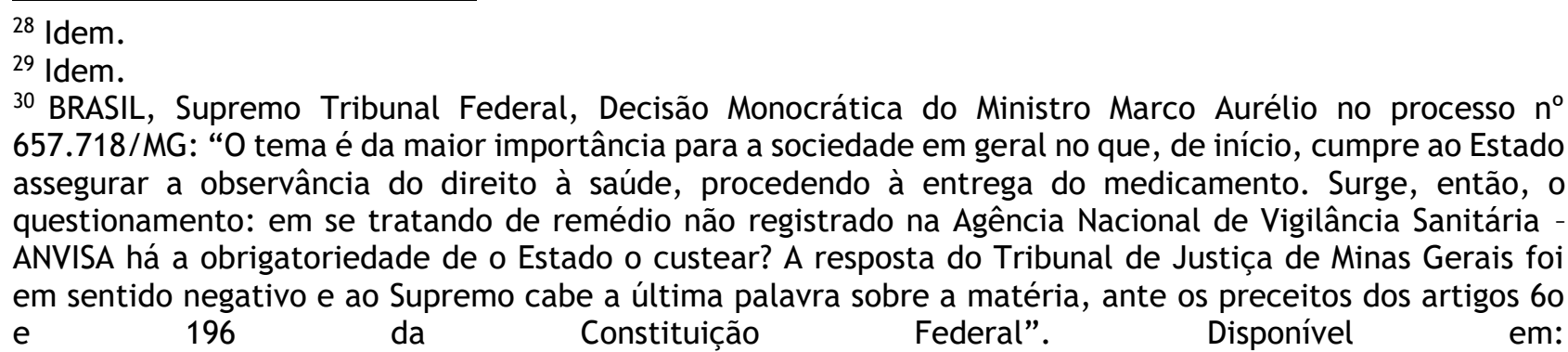
http:/ / www.stf.jus.br/portal/jurisprudenciaRepercussao/verPronunciamento.asp?pronunciamento=38157 05\&tip=manifestacao Acesso em 8 mai. 2018.

31 Informativo $\mathrm{n}^{\circ} 841$ do Supremo Tribunal Federal de 10 de outubro de 2016. Disponível em: http://www.stf.jus.br/arquivo/informativo/documento/informativo841.htm. Acesso em mai. 2018. 
Embora o Ministro tenha tido o cuidado de ressalvar que o art. 12 da Lei $n^{\circ} 6.360 / 1976^{32}$ é explícito ao vedar a industrialização, a exposição à venda ou a entrega ao consumo de medicamento sem o prévio registro junto à Anvisa, e que a liberação dada pelo Judiciário seria “excepcional”, a tão-só possibilidade de autorização do Poder Judiciário para assegurar o fornecimento das mesmas substâncias que a lei penal buscou recriminar, notadamente de substâncias medicinais ou terapêuticas não autorizadas pela Anvisa, revela uma fragilidade na premissa que sustenta a persecutio criminis para a hipótese.

Afinal, a ótica adotada pelo legislador ao editar o $\$ 1^{\circ}$-B do artigo 273 do Código Penal foi no sentido de que o fornecimento de medicamentos não registrados na Anvisa constitui, por si só, um atentado ao bem jurídico protegido “saúde pública”. Foi por essa razão, inclusive, que a hipótese deixou de ser classificada como crime de perigo concreto e passou a ser enquadrada como crime de perigo abstrato, o que significa que o legislador pressupôs que o tão-só fornecimento de medicamentos sem a aprovação da Anvisa representaria um risco tão elevado que o agente que the desse causa deveria ser privado de sua liberdade por 10 a 15 anos.

Contudo, a autorização dada pelo Judiciário para que medicamentos sem registro na Anvisa sejam fornecidos em determinados casos, ainda que específicos, indica que o fornecimento de substâncias que não contenham registro não necessariamente implica em risco de dano à saúde pública, o que sugere, por sua vez, a possibilidade de se abrandar o tipo penal, para flexibilizá-lo à luz do caso concreto. Isso atrai o questionamento quanto ao seu enquadramento como hipótese de "perigo abstrato". Se é possível flexibilizar a premissa da regra administrativa, parece razoável dizer que a regra penal deve comportar a mesma flexibilização.

A bem da verdade, não houve simples flexibilização da premissa de dano abstrato que norteou a edição da regra penal. O Judiciário passou a adotar uma interpretação totalmente casuística acerca dos critérios necessários para a proteção do bem jurídico saúde pública, em muitos casos priorizando outros parâmetros que não o registro na Anvisa ${ }^{33}$. A exigência do registro

\footnotetext{
${ }^{32}$ BRASIL, Lei $n^{\circ}$ 6.360, de 23 de setembro de 1976. Dispõe sobre a Vigilância Sanitária a que ficam sujeitos os Medicamentos, as Drogas, os Insumos Farmacêuticos e Correlatos, Cosméticos, Saneantes e Outros Produtos. In: Diário Oficial da República Federativa do Brasil, Brasília, DF, 24 set. 1976. Disponível em http:// www.planalto.gov.br/ccivil_03/leis/l6360.htm?TSPD_101_R0=827811dd9dba6b3420f0cdafd692d9c14 a190000000000000000ae8a3cbdffff00000000000000000000000000005af1b38d00a8b5ba78 Acesso em 8 mai. 2018.

33 BOTTINI, Pierpaolo. Crimes de Perigo Abstrato e Princípio da Precaução na Sociedade de Risco, São Paulo: Revistas dos Tribunais. 2007. p. 231/232. O autor ao tratar em obra específica sobre os crimes de perigo abstrato, destaca a dificuldade relacionada à aplicação dos crimes de perigo abstrato e a interpretação casuística do Judiciário ao enfrentar casos concretos. Pondera o autor que: "Os tribunais brasileiros vêm dedicando atenção à questão dos crimes de perigo abstrato e, em alguns casos, decidindo pela atipicidade diante da ausência de periculosidade nos casos concretos. No entanto, os fundamentos de tais decisões são variados, em geral voltados para peculiaridades dos dispositivos da Parte Especial dos
} 
passou a ser indicada, em alguns casos, não como um instrumento de proteção, mas uma exigência execrável, porque prejudicial à proteção do bem tutelado pelo artigo 196 da Constituição Federal - que estabelece que a saúde é direito de todos e dever do Estado, que deve ser garantido mediante políticas sociais e econômicas que visem à redução do risco de doença e de outros agravos, e ao acesso universal e igualitário às ações e serviços para sua promoção, proteção e recuperação.

Não é incomum, por isso mesmo, o Judiciário determinar o fornecimento de medicamentos sem qualquer oitiva da Agência Reguladora, muito embora seja ela, ao menos em tese, a responsável por zelar pela saúde pública ${ }^{34}$. Para ficar em dois exemplos, ao julgar a Suspensão de Segurança $n^{\circ}$ 4.316, em 7 de junho de 2011, o Presidente do Supremo Tribunal Federal, Ministro Cezar Peluso, determinou ao Estado que fornecesse o medicamento Soliris (Eculizumabe), conquanto ainda não estivesse registrado na Anvisa, por entender que a medicação em questão é "reconhecida pela comunidade médica como a única medicação eficaz para o tratamento da doença Hemoglobinúria Paroxística Noturna - HPN”35. Por sua vez, no dia 7 de agosto de 2017, a Ministra Cármen Lúcia, ao apreciar uma Medida Cautelar no bojo da Suspensão de Segurança $n^{\circ}$ 5.192, assegurou a um jurisdicionado o fornecimento do medicamento Spinraza para o tratamento de uma doença degenerativa que causa atrofia muscular espinhal. Entendeu a

Código Penal ou baseados no princípio da insignificância. No entanto, não se observa, em geral, o reconhecimento da periculosidade como critério de relevância penal das condutas, o que resulta em decisões casuísticas e desarticuladas, sem um norte interpretativo que confira estabilidade à jurisprudência sobre o tema. (...) A constelação de respostas diversas e casuísticas que buscam justificar a não aplicação dos tipos de perigo abstrato a hipóteses em que o direito penal não é útil ou necessário poderia ser organizada e sistematizada sob o denominador comum da periculosidade, como elemento da conduta típica. Dessa forma, a linha de interpretação seria consolidada sob critérios definidos e claros, garantindo a segurança sobre a aplicação dos tipos penais em análise".

${ }^{34}$ Sobre o tema também se posicionou a jurista Janaina Conceição Paschoal, que assim ponderou: "Como dito no início, a fim de contornar a desproporcionalidade da pena cominada pelo art. 273 do CP, muitos julgadores têm interpretado tal dispositivo em conjunto com a lei de drogas, aplicando as penas previstas para o tráfico, atitude adequada, quando se está diante de uma efetiva falsificação de produto medicinal, ou da comercialização do produto adulterado. (...) De certa forma, os julgadores têm contemporizado os desmandos que a exacerbada punição e a péssima redação do art. 273 do CP permitem. Não obstante, como apontado no início, vários magistrados, fortalecidos na doutrina, findam por prolatar decisões injustas, sob o argumento de que o juiz não pode legislar, mesmo quando em favor do imputado. In PASCHOAL, Janaina Conceição. A falsificação de remédios, a combinação de normas e a importação de medicamento. IBCCRIM. Boletim - 234 - Maio / 2012.

35 BRASIL, Supremo Tribunal Federal. Suspensão de Segurança $n^{\circ} 4.316 / R O$, Relator Ministro Presidente Cezar Peluso, apreciado em 7 de junho de 2011. Decisão disponível em http://stf.jus.br/portal/processo/verProcessoTexto.asp?id=3000680\&tipoApp=RTF Acesso em 8 mai. 2018. 
Ministra que esse era "o único eficaz disponível para o tratamento clínico da doença", muito embora o medicamento não estivesse registrado na Anvisa ${ }^{36-37}$.

Em ambos os casos acima o elemento considerado primordial para a proteção da saúde pública - qual seja, o registro na Anvisa - teve menos relevância do que o entendimento dos médicos dos respectivos pacientes e mesmo o "reconhecimento da comunidade médica", para citar a expressão cunhada pelo Ministro Cezar Peluso. Houvesse o fornecimento das mesmas substâncias não registradas na Anvisa sem respaldo do Judiciário, ainda que amparado por expressa determinação médica e mesmo do apoio da comunidade médica, aquele que procedesse com a importação ou produção, com a consequente venda da substância, estaria cometendo o crime do inciso I do $\$ 1^{\circ}$-B do artigo 273.

Nesse sentido, a atual interpretação adotada pelo Supremo para autorizar o fornecimento de medicamentos e substâncias medicinais que não estão registradas na Anvisa deve conduzir ao reconhecimento de que é necessário dar nova interpretação à regra estabelecida no § $1^{\circ}$-B do artigo 273 do Código Penal.

Afinal, a proteção da saúde pública, objeto jurídico protegido da norma penal, parece transbordar a questão relacionada ao simples registro perante a Agência Reguladora. Se, para o STF, o registro, visto isoladamente, constitui uma exigência burocrática que muitas vezes se transforma em um elemento prejudicial à proteção do mesmo bem jurídico que a norma penal buscou proteger, resta desautorizado o enquadramento da hipótese de mero fornecimento sem registro de um medicamento como um crime de perigo abstrato. 0 tipo penal deve admitir, por isso, interpretação conforme à Constituição, para the atribuir o sentido e a aplicação correta.

\section{O INDEVIDO ENQUADRAMENTO DA HIPÓTESE DO INCISO I DO \$1-B COMO UM CRIME DE PERIGO ABSTRATO.}

Os crimes de perigo abstrato são aqueles em que há a mera potencialidade de dano. Eles se consumam em uma situação hipotética de perigo, na qual, mediante uma concepção juris

\footnotetext{
${ }^{36}$ BRASIL, Supremo Tribunal Federal. Suspensão de Segurança $n^{\circ}$ 5.192/RO, Relatora Ministra Presidente Carmén Lúcia, apreciado em 16 de agosto de 2017. Decisão disponível em http://stf.jus.br/portal/processo/verProcessoPeca.asp?id=312439101\&tipoApp=.pdf Acesso em 8 mai. 2018.

${ }^{37}$ Ambos os medicamentos foram posteriormente registrados na Anvisa, conforme noticiado em sua página de internet: http://portal.anvisa.gov.br/noticias/-/asset_publisher/FXrpx9qY7FbU/content/anvisaconcede-registro-ao-medicamento-spinraza/219201/; e $\quad$ http://portal.anvisa.gov.br/noticias//asset_publisher/FXrpx9qY7FbU/content/doencas-raras-ganham-dois-novos-tratamentos/219201. Consulta em 8 mai. 2018.
} 
et de jure, realiza-se um juízo ex ante ${ }^{38}$. É dizer, não é necessário que haja a consumação do prejuízo ou risco real decorrente da conduta do agente para que haja a subsunção ao tipo penal. Ao revés, basta que haja a prática do ato tipificado na lei para a consumação do crime ${ }^{39}$.

Como leciona Pierpaolo Bottini, o tipo penal do crime de perigo abstrato está relacionado à preocupação cada vez maior, na atual sociedade de risco, de se dar maior proteção dos bens jurídicos coletivos, em especial por conta da complexidade das relações de produção e distribuição de insumos, com a massificação do consumo e a formação de intrincadas estruturas organizacionais que dificultam a identificação da relação de causalidade entre uma conduta e um resultado danoso ${ }^{40}$. Dentre os bens jurídicos protegidos geralmente é enquadrada a saúde pública, ainda que esse enquadramento seja passível de crítica, como veremos adiante.

A intenção de transformar a hipótese contida no $§ 1^{\circ}$-B do artigo 273 do Código Penal foi justamente de evitar que, com a comercialização de produtos que ainda não passaram pelo crivo da Agência Nacional de Vigilância Sanitária, houvesse um risco hipotético para a população. O problema está quando uma parcela relevante das ações praticadas que se amoldam na norma incriminadora não representa ameaça à saúde pública. É a hipótese que se apresenta justamente nos casos de decisões judiciais ordenando o fornecimento de medicamentos sem registro.

0 próprio Judiciário tem refutado a premissa do perigo abstrato que foi insculpida no inciso I do $\$ 1^{\circ}$ - $\mathrm{B}$ ao autorizar o fornecimento de medicamentos que ainda não foram liberados pela Anvisa, para isso, ironicamente, tendo por fundamento a disposição do artigo 196 da Constituição, que prevê que a saúde é um direito de todos e um dever do Estado, que deve dar garantias de acesso universal e igualitário às ações e serviços para garantir a promoção da saúde, com a redução do risco de doenças e outros agravos.

Cumpre indagar, assim, se o fornecimento de medicamentos sem a prévia autorização da Anvisa é, efetivamente, e por si só, um ato capaz de gerar uma ameaça abstrata de dano à saúde da população. Afinal, a conduta tipificada pelo legislador, para ser elegível ao critério de um crime de perigo abstrato, não apenas deve ofender um bem jurídico merecedor da tutela penal, como deve configurar um ato justificadamente ameaçador ${ }^{41}$. Não parece ser esse o caso do

\footnotetext{
${ }^{38}$ SILVEIRA, Renato de Mello Jorge. Novas Considerações Quanto à Proteção Penal da Saúde Pública, em Doutrinas Essenciais de Direito Penal Econômico e da Empresa. Vol. 3. Julho de 2011. p. 1185/1193.

${ }^{39}$ ROXIN, Claus. Derecho Penal: Parte General, Tomo I, p. 407.

${ }^{40}$ BOTTINI, Pierpaolo Cruz. In Crimes de Perigo Abstrato e Princípio da Precaução na Sociedade de Risco, São Paulo: Revistas dos Tribunais. 2007. p. 120/121.

${ }^{41}$ AGUADO CORREA, Teresa. El principio de proporcionalidad en Derecho Penal. Madrid: Edersa. 1999, pp. 341 e ss.
} 
fornecimento de medicamentos sem registro, dado que não necessariamente a produção e o fornecimento de medicamentos, em si, implicará qualquer risco ao bem jurídico saúde pública.

A bem da verdade, o dito bem jurídico protegido "saúde pública" nada mais é do que a soma de bens individuais, uma vez que não existe um bem coletivo juridicamente protegido como ocorre, por exemplo, com o meio ambiente, que, conceitualmente, está ao alcance de todos e, por isso mesmo, sujeito a repercussão das ações individuais e coletivas de forma similar. Esse também é o entendimento do professor Luís Greco, que pondera tratar-se a "saúde pública" da "soma das várias integridades físicas individuais, de maneira que não passa de um pseudo bem coletivo" ${ }^{42}$.

Se, para a proteção da integridade física individual de muitos cidadãos, é necessário recorrer ao Judiciário de forma que ele excepcione justamente o tipo penal estabelecido no inciso I do $§ 1^{\circ}$-B do artigo 273 do Código Penal, assim como a regra do artigo 12 da lei $n^{\circ} 6.360 / 1976{ }^{43}$, e autorize o fornecimento de um medicamento que não é produzido ou comercializado no país como consequência direta ou indireta daquela regra penal e de outras restrições impostas pelo legislador (ex vi o disposto no artigo 334-A do Código Penal), então parece certo que aquela restrição é inadequada e muitas vezes danosa ao bem jurídico ao qual ela foi concebida para proteger.

O Judiciário reforça essa inadequação sempre que decide na linha do que ponderou a Ministra Cármen Lúcia na Suspensão de Segurança $n^{\circ} 5.192$, no sentido de que o fornecimento do medicamento não autorizado pela Anvisa é o “único instrumento eficaz disponível” para o tratamento clínico de determinada doença.

Discussão similar chegou ao Superior Tribunal de Justiça, sobre a aplicação do tipo penal disposto no art. $7^{\circ}$, inciso IX, da Lei $n^{\circ} 8.137 / 1990$, e no art. 18 da Lei $n^{\circ} 8.078 / 90$. Esses dispositivos tratam do crime abstrato de dano da venda de produtos alimentícios com prazo de validade expirado. A Corte tem entendido que, tratando-se de uma infração que deixa vestígio, é imprescindível a realização de exame de corpo de delito direto, por expressa imposição legal, e assim à luz do artigo 158 do Código Penal, que estabelece que "quando a infração deixar vestígios,

\footnotetext{
${ }^{42}$ GRECO, Luís. Princípio da ofensividade e crimes de perigo abstrato - uma introdução ao debate sobre o bem jurídico e as estruturas do delito. Revista Brasileira de Ciências Criminais: RBCCrim, v. 12, n. 49, p. 89-147, jul./ago. 2004.

${ }^{43}$ BRASIL, Lei $n^{\circ}$ 6.360, de 23 de setembro de 1976. Dispõe sobre a Vigilância Sanitária a que ficam sujeitos os Medicamentos, as Drogas, os Insumos Farmacêuticos e Correlatos, Cosméticos, Saneantes e Outros Produtos. In: Diário Oficial da República Federativa do Brasil, Brasília, DF, 24 set. 1976. Disponível em http://www.planalto.gov.br/ccivil_03/leis/l6360.htm?TSPD_101_R0=827811d9dba6b3420f0cdafd692d9c14 a190000000000000000ae8a3cbdffff00000000000000000000000000005af1b38d00a8b5ba78 Acesso em 8 mai. 2018.
} 
será indispensável o exame de corpo de delito, direto ou indireto, não podendo supri-lo a confissão do acusado" ${ }^{44}$. Se para produtos alimentícios vencidos e não fiscalizados permite-se, ainda que casualmente, a amortização da regra penal para afastar a sua aplicação, com mais razão parece ser o caso com medicamentos e congêneres que dependem de registro perante a Anvisa, atividade majoritariamente burocrática e administrativa.

Vale fazer o paralelo, neste ponto, ao que decidiu o STF, na oportunidade do julgamento do Habeas Corpus n 104.410/RS, em março de 2012, relatado pelo Ministro Gilmar Mendes. Tratava aquela hipótese do risco advindo do porte de arma de fogo desmuniciada e da sua persecução criminal. Entendeu o Ministro que "não serão idôneos para a proteção de determinado bem jurídico os atos legislativos criadores de tipos de perigo abstrato que incriminem meras infrações administrativas, as quais não têm aptidão para produzir, sequer potencialmente, qualquer perigo em concreto para o bem jurídico em questão".

Como colocado pelo Ministro, os crimes de perigo abstrato devem restringir-se aos comportamentos que, segundo os diagnósticos e prognósticos realizados pelo legislador com base em dados e análises científicas disponíveis no momento, geralmente configuram perigo para o bem jurídico protegido, descartados aqueles que apenas de forma isolada ou excepcional podem ensejar tal perigo. Concluiu o Ministro em seu voto:

Quando houver medidas mais eficazes para a proteção do bem jurídico-penal, porém menos gravosas para os direitos individuais em jogo, os crimes de perigo abstrato serão contrários aos princípios da subsidiariedade e da ofensividade e, dessa forma, ao princípio da proporcionalidade. Meros ilícitos que são objeto de responsabilização jurídica eficaz por meio do Direito Civil ou do Direito Administrativo tornam desnecessária a intervenção do Direito Penal, que deve operar apenas como ultima ratio ${ }^{45}$.

\footnotetext{
${ }^{44}$ (...) A hodierna jurisprudência das Turmas que compõem a Terceira Seção deste Superior Tribunal entende que, para a configuração do tipo penal descrito no art. $7^{\circ}$, IX, da Lei n. 8.137/1990, impõe-se a demonstração inequívoca da impropriedade do produto. 2. Por ser infração que deixa vestígio, é imprescindível a realização de exame de corpo de delito direto, por expressa imposição legal. Somente pode ser substituído o laudo pericial por outros meios de prova se o delito não deixar vestígios, se estes tiverem desaparecido ou, ainda, se as circunstâncias do crime não permitirem a confecção do laudo. (...) (AgRg no REsp 1300606/DF, Rel. Ministro Rogerio Schietti Cruz, Sexta Turma, julgado em 07/03/2017, DJe 14/03/2017). No mesmo sentido: REsp 1575406/SP e REsp 1369828/DF, da mesma Relatoria, julgados em 22/08/2017 e 06/05/2014.

${ }^{45}$ No mesmo sentido v. AGUADO CORREA, Teresa. El principio de proporcionalidad en Derecho Penal. Madrid: Edersa; 1999, p. 394. Destacamos: "Para que los delitos de peligro abstracto resulten compatibles con el principio de ofensividad es necesario: por una parte, que a través de los mismos se intente proteger bienes jurídicos merecedores de pena, es decir, constitucionalmente legítimos y dotados de una especial relevancia social, puesto que implican una ampliación muy importante de la tutela penal; por otra parte, que a través de los delitos de peligro abstracto se tipifiquen aquellas conductas que aparezcan como generalmente peligrosas para el bien jurídico que se trata de proteger, y no aquellas conductas que sólo
} 
A hipótese é de todo similar àquela que discute o enquadramento do fornecimento de medicamentos sem registro enquanto crime de perigo abstrato. É razoável enquadrar a tão-só falta do registro, hipótese de infração administrativa, como causa de concreta ameaça à saúde pública?

É interessante conjugar essa questão com aquela enfrentada pelo Supremo Tribunal Federal no bojo da Medida Cautelar proposta na Ação Direta de Inconstitucionalidade $n^{\circ} 5501 / D F$, em que se questiona a constitucionalidade da Lei $n^{\circ} 13.269 / 2016$, que autorizou a utilização da substância fosfoetanolamina sintética por pacientes diagnosticados com neoplasia maligna - a polêmica "pílula do câncer". A discussão travada naquele caso diz respeito à possibilidade de o legislador autorizar a comercialização de uma droga que jamais passou por qualquer estudo clínico que comprovasse a sua eficácia e segurança e que, justamente por conta disso, carece de registro junto à Agência Nacional de Vigilância Sanitária. Trata-se de hipótese frontalmente oposta àquela proposta através da “Lei dos Remédios”. Por maioria de votos, o Supremo suspendeu a eficácia da lei em sede cautelar.

Embora o mérito da questão ainda esteja sendo discutido pela Corte, chama a atenção o voto do Ministro Edson Fachin, no que ele se preocupou em destacar o papel da Agência Reguladora na implementação das políticas públicas voltadas à proteção do bem jurídico saúde pública:

...entendo que o uso privado de substâncias, ainda que apresentem eventuais efeitos nocivos à saúde humana, insere-se no âmbito da autonomia privada e está imune à interferência estatal em matéria penal.

A rigor, o uso da substância fosfoetanolamina é permitido se não há lei que o proíba. Registre-se, no entanto, que ainda que eventualmente opte o legislador para proibí-la, cominando, para tanto, uma pena, encontraria limite claro no princípio da ofensividade. Foi o que consignei no voto do RE 635.659:

“(...) O ponto de partida para se delimitar o campo de restrição à autonomia parece estar no princípio da ofensividade: somente havendo dano efetivo, porquanto haveria, por conseguinte, uma interferência na autonomia das outras pessoas, é que se pode legitimar a coerção.

A sanção penal é, assim, tão-só uma das formas de se proteger os bens jurídicos. Consubstanciando a mais grave restrição na autonomia dos cidadãos, cumpre, portanto, avaliar se ela é adequadamente posta. E é aqui que tem assento a proporcionalidade.

Especificamente em relação à coerção penal, poder-se-ia apontar, na linha do que indica Claus Roxin, serem ilegítimas as incriminações de: motivações ideológicas; autolesão; tabus; fins extrapenais; e abstrações incapazes de constituir bens jurídicos (ROXIN, Claus. Es la protecion de los bienes jurídicos una finalidad del derecho penal? In: La teoría del bien jurídico. Fundamentos de legitimación del derecho penal o juego de laboratorios dogmáticos? Roland Hefendehl (ed.). Barcelona: Marcial Pons, 2007).

en algunos casos aparecen como peligrosas; en último lugar, que en el caso concreto el comportamiento sea efectivamente peligroso para el bien jurídico protegido". 
Essas considerações parecem indicar que, em vista da ofensa a um bem individual, não se pode dar ensejo à criminalização. Esse norte tem sentido especialmente para o adicto, usuário dependente de droga; impende ajudar o usuário que queira se livrar do poder criminoso da dependência. Frise-se, relativamente a esta inferência, que não se visa inviabilizar a atividade regulatória do Estado, nem mesmo a de imposição de sanções, mas a afastar que a regulação seja feita por meio da coerção penal como primeiro antídoto".

Conquanto não seja possível, sob a perspectiva penal, tipificar o uso da fosfoetanolamina, poder-se-ia perguntar se, considerando sua aplicação a "pacientes diagnosticadas com neoplasia maligna", não deveria a substância ser regulada administrativamente. A resposta é afirmativa.

Nos termos do art. 200, I, da Constituição Federal, compete ao sistema único de saúde "controlar e fiscalizar procedimentos, produtos e substâncias de interesse para a saúde e participar da produção de medicamentos, equipamentos, imunobiológicos, hemoderivados e outros insumos". O sistema único é definido pela Lei 8.080/90 como sendo "o conjunto de ações e serviços de saúde, prestados por órgãos e instituições públicas federais, estaduais e municipais, da Administração direta e indireta e das fundações mantidas pelo Poder Público" (art. $4^{\circ}$, caput).

Essa mesma lei, atribui ao órgão de vigilância sanitária, conforme previsão constante de seu art. $6^{\circ}, \S 1^{\circ}, \mathrm{l}$, as competências para o "controle de bens de consumo que, direta ou indiretamente, se relacionem com a saúde, compreendidas todas as etapas e processos, da produção ao consumo". Note-se que a Lei em questão se refere à "substância" e não a "medicamento" ou "suplemento alimentar".

A execução dessa política de controle está a cargo da Anvisa, a agência responsável pelas ações de vigilância sanitária (art. $6^{\circ}$, I, “a”, e $\S 1^{\circ}$, da Lei 8.080 e art. $4^{\circ}$ da Lei 9.782) que detém a competência para "regulamentar, controlar e fiscalizar os produtos e serviços que envolvam risco à saúde pública" (art. $8^{\circ}$, caput, da Lei 9.782) ${ }^{46}$.

O entendimento do Ministro Edson Fachin é, em poucas palavras, que não há lei que vede o uso da substância fosfoetanolamina sintética e que, ainda que houvesse, ela encontraria limite claro no "princípio da ofensividade". De acordo com esse princípio, só são passíveis de punição as condutas que lesionem ou coloquem em perigo um bem jurídico penalmente tutelado. Na posição do Ministro, a liberação do uso da fosfoetanolamina sintética não necessariamente pode colocar em risco o bem jurídico saúde pública, sob a ótica de que o uso individual de uma droga não autorizada pela Anvisa não configura hipótese passível de ser enquadrada como danosa à saúde pública.

Embora, não se possa tipificar o uso da fosfoetanolamina, a comercialização desse medicamento, enquanto ele não tiver sido examinado pela Anvisa, foi vedada pelo legislador, assim como a sua importação, e essa proibição esbarra justamente na hipótese que o Ministro

46 BRASIL, Supremo Tribunal Federal. ADI 5501 MC, Relator Min. MARCO AURÉLIO, Tribunal Pleno, julgado em 19/05/2016, DJe-168 PUBLIC 01-08-2017. 
corretamente recriminou, qual seja, de "que a regulação seja feita por meio da coerção penal como primeiro antídoto". O voto não poderia ser mais acertado.

Esse entendimento é, por tudo, muito relevante para o exame da norma penal prevista no inciso I do $\$ 1^{\circ}$-B do artigo 273 do Código Penal. Se o uso individual não implica em risco à saúde pública, a venda sem o registro também não pode ser enquadrada como tal. Nada impede, por exemplo, que a aquisição do medicamento esteja condicionada à prévia autorização e à apresentação de prescrição médica - mesmos critérios usualmente adotados pelo Judiciário para determinar o fornecimento de medicamento sem registro.

Há, portanto, outros instrumentos possíveis, menos gravosos aos direitos individuais em jogo, para resguardar a saúde pública, enquanto bem jurídico tido por protegido ${ }^{47}$. Havendo alternativas à adoção do direito penal como prima ratio no que tange ao fornecimento de medicamentos e congêneres não registrados na Anvisa, demonstra-se equivocada a opção do legislador de enquadrar como crime de perigo abstrato a hipótese de fornecimento de medicamentos e demais substâncias sem registro. Os instrumentos de proteção da saúde, ao revés, devem ser tratados, antes, na esfera administrativa e regulatória.

\section{O DIREITO PENAL DEVE SER O ÚLTIMA RATIO: A REGULAÇÃO DA SAÚDE PÚBLICA COMPETE À AGÊNCIA REGULADORA, QUE DEVE APRIMORAR OS INSTRUMENTOS DE CONTROLE.}

Um ponto que não pode escapar à análise na discussão aqui proposta é que a Agência Nacional de Vigilância Sanitária foi criada pelo legislador menos de um ano depois da promulgação da malfadada “Lei dos Remédios". Ela foi criada pela Lei de $n^{\circ}$ 9.782/1999 ${ }^{48}$ justamente para regular e fiscalizar matérias relacionadas à saúde pública.

\footnotetext{
${ }^{47}$ SILVA FRANCO, Alberto. Crimes Hediondos. 4 Edição. São Paulo: Revistas dos Tribunais, 2000. p.67: “O princípio da proporcionalidade exige que se faça um juízo de ponderação sobre a relação existente entre o bem que é lesionado ou posto em perigo (gravidade do fato) e o bem de que pode alguém ser privado (gravidade da pena). Toda vez que, nessa relação, houver um desequilíbrio acentuado, estabelece-se, em consequência, inaceitável desproporção. 0 princípio da proporcionalidade rechaça, portanto, o estabelecimento de cominações legais (proporcionalidade em abstrato) e a imposição de penas (proporcionalidade em concreto) que careçam de relação valorativa com o fato cometido considerado em seu significado global. Tem, em consequência, um duplo destinatário: o poder legislativo (que tem de estabelecer penas proporcionadas, em abstrato, à gravidade do delito) e o juiz (as penas que os juízes impõem ao autor do delito têm de ser proporcionadas à sua concreta gravidade)."

48 BRASIL, Lei $n^{\circ}$ 9.782, de 26 de janeiro de 1999. Dispõe sobre o Sistema Nacional de Vigilância Sanitária, cria a Agência Nacional de Vigilância Sanitária, e dá outras providências. In: Diário Oficial da República Federativa do Brasil, Brasília, DF, 27 jan. 1999. Disponível em http://www.planalto.gov.br/ccivil_03/leis/19782.htm?TSPD_101_R0=4ac3c8e7fdac0120ab1441acbe46b55d
} 
Estabeleceu o legislador, no artigo $6^{\circ}$ da lei, que a finalidade institucional da Agência seria justamente de promover a proteção da saúde da população, por intermédio do controle sanitário da produção e comercialização de produtos e serviços submetidos à vigilância sanitária ${ }^{49}$, e, no artigo $8^{\circ}$, que compete à Anvisa regulamentar, controlar e fiscalizar os produtos e serviços que envolvam risco à saúde pública ${ }^{50}$.

Com base nestes dispositivos, a Anvisa edita periodicamente uma tabela que contém as substâncias cuja comercialização é vedada justamente por implicarem em ameaça à saúde dos consumidores e, como reflexo, um risco ao bem jurídico saúde pública. A Agência ainda discrimina as substâncias que devem ficar sujeitas à venda sob prescrição médica e mesmo à retenção de receita pelo estabelecimento, como forma de controlar a venda de substâncias medicinais e terapêuticas previamente registradas na Anvisa ${ }^{51}$.

Esse nos parece ser o ponto relevante para a delimitação do tipo penal: a comercialização de uma substância que já foi enquadrada como nociva à saúde pela Agência Reguladora é muito diferente da comercialização de uma substância que ainda não passou pelo crivo da Agência.

Por mais que se possa apontar riscos advindos da comercialização de um produto que ainda não tenha passado pela análise da agência de vigilância sanitária, não parece razoável equiparar este fato à venda de uma substância proibida, ao menos para fins de persecução penal. Apenas a comercialização de substâncias e medicamentos expressamente elencados pela Agência como nocivos à saúde é que parece justificar a persecutio criminis enquanto primeiro instrumento de coerção, pois, nesses casos, há elementos concretos que apontam para a potencialidade de dano.

Essa distinção nos permite traçar cenários absolutamente diferentes e que deveriam ter tratamento diferente pela legislação, mas que, ao revés, não sofreram qualquer distinção à luz da norma penal.

ID60000000000000000ae8a3cbdffff00000000000000000000000000005af12be900f13ac244 Acesso em 8 mai. 2018.

${ }^{49}$ Art. $6^{\circ} \mathrm{A}$ Agência terá por finalidade institucional promover a proteção da saúde da população, por intermédio do controle sanitário da produção e da comercialização de produtos e serviços submetidos à vigilância sanitária, inclusive dos ambientes, dos processos, dos insumos e das tecnologias a eles relacionados, bem como o controle de portos, aeroportos e de fronteiras.

${ }^{50}$ Art. $8^{\circ}$ Incumbe à Agência, respeitada a legislação em vigor, regulamentar, controlar e fiscalizar os produtos e serviços que envolvam risco à saúde pública.

${ }^{51}$ BRASIL. ANVISA. Portaria $n^{\circ} 344$, de 12 de maio de 1998. Aprovou o Regulamento Técnico sobre substâncias e medicamentos sujeitos a controle especial. In: Diário Oficial da República Federativa do Brasil, Brasília, DF, 31 dez. 1998. Disponível em: http://www4.anvisa.gov.br/base/visadoc/port/port[939-2-0].htm. Acesso em 28 out. 2017. 
Há, assim, a hipótese de substâncias consideradas nocivas pela Anvisa e que estão expressamente proibidas - substâncias e medicamentos proscritos - de serem fabricadas e comercializadas, em razão dos notórios efeitos adversos que produzem à saúde humana. Parece razoável dizer que, nesses casos, o desrespeito ao comando normativo da Agência, que veda a sua produção e comercialização, justifica a aplicação do crime de perigo concreto, devendo ser admitida prova em contrário por parte daquele que praticar o ato recriminado pela norma penal, a fim de comprovar a ausência de perigo para a saúde pública. Afinal, como o próprio artigo $6^{\circ}$ da Lei $n^{\circ} 6.360 / 1977^{52}$ deixa claro, os critérios técnicos podem mudar. Segundo esse dispositivo, um medicamento antes admitido pela Vigilância Sanitária pode posteriormente ser considerado nocivo à saúde humana. Pela mesma lógica, um produto antes considerado nocivo pode ser admitido pela Agência.

Há, por outro lado, a hipótese de produção e venda de substâncias e medicamentos que não possuem registro na Agência Reguladora, mas que tampouco são elencados como produtos nocivos à saúde humana. Nestes casos, a falta de registro tanto pode decorrer de mora da Agência, quanto da omissão do fabricante, situações essas que diferem da hipótese anterior, de venda de substâncias proibidas. Nesses casos, não há espaço para falar em crime de perigo enquanto não comprovado o risco à saúde humana. Assim, a hipótese comporta o enquadramento como crime de perigo concreto, isto é, em que o perigo de dano deve ser comprovado ainda que minimamente para justificar a persecutio criminis, admitindo-se prova em contrário para afastar o tipo penal.

A hipótese mais grave é aquela que diz respeito à mora da Agência Reguladora em efetivar o registro. Esse ponto é relevante em especial por constatações de ordem prática: a Anvisa demora em torno de 632 dias para concluir o registro de um remédio novo, 1062 dias no caso de genérico e 1225 para medicamento similar ${ }^{53}$, tudo conforme informações dadas pelo próprio presidente da autarquia ${ }^{54}$.

\footnotetext{
${ }^{52}$ BRASIL, Lei ${ }^{\circ} 6.360$, de 23 de setembro de 1976. Dispõe sobre a Vigilância Sanitária a que ficam sujeitos os Medicamentos, as Drogas, os Insumos Farmacêuticos e Correlatos, Cosméticos, Saneantes e Outros Produtos. In: Diário Oficial da República Federativa do Brasil, Brasília, DF, 24 set. 1976. Disponível em http://www.planalto.gov.br/ccivil_03/leis/l6360.htm?TSPD_101_R0=827811d9dba6b3420f0cdafd692d9c14 a190000000000000000ae8a3cbdffff00000000000000000000000000005af1b38d00a8b5ba78 Acesso em 8 mai. 2018.

53 Medicamentos genéricos e similares apresentam, por essência, o mesmo princípio ativo que um medicamento de referência, do que decorre que, comprovada a sua identidade com um remédio registrado na Anvisa, ainda que não registrados na Agência Reguladora, não parece razoável autorizar a aplicação da norma penal estabelecida pelo legislador no $\$ 1^{\circ}$-B do artigo 273 do código Penal.

54 BRASIL, Senado Federal. Informação do Senado Notícias. Disponível em https: / / www12.senado.leg.br/noticias/materias/2016/03/09/necessidade-de-agilizar-registro-demedicamentos-e-consenso-em-debate-na-cas
} 
Como pontuou Miguel Reale Junior, a norma penal acabou por criar distorções, transformando "em crime hediondo a venda de medicamentos, muitas vezes de última geração, em razão do descaso ou desorganização da Administração, que não concede o registro no prazo legal, aliás excedendo-o em alguns anos, desatendendo ao princípio da eficiência, recentemente incluído no art. 37 da CF (LGL\1988\3), como norteador da Administração Pública"55.

Há, por fim, casos em que não houve o registro junto à Anvisa de medicamentos que já contam com o aval da comunidade científica e mesmo de renomadas agências estrangeiras, sendo as mais conhecidas a Food and Drug Administration (FDA), a Agência Europeia de Medicamentos (EMEA) e a Agência de Produtos Farmacêuticos e Equipamentos Médicos do Japão (PMDA). Se o Judiciário, em muitos casos, se vale desse elemento para autorizar a importação de medicamentos sem registro na Anvisa, a exemplo do que se ponderou o Ministro Luís Roberto Barroso no voto dado no Recurso Extraordinário $\mathrm{n}^{\circ} 657.718 / \mathrm{MG}^{56}$, parece certo dizer que esse mesmo elemento deveria servir de parâmetro para afastar a aplicação do tipo penal estabelecido no $\$ 1^{\circ}$-B do artigo 273.

Dito isso, em todas as hipóteses a ausência do registro de determinado medicamento não implica, por si só, que esse medicamento não possa vir a ser recomendado pela comunidade médica ou que ele não possa ser benéfico para determinado tratamento. Essa interface compete à regulação, e não ao direito penal. A norma penal não deve servir de alicerce para inverter o papel da regulação, como registrou Antônio Celso Campos de Oliveira Faria, afirmando que a lei penal não se presta a sanar problemas de natureza eminentemente regulatória:

As farmácias deveriam ter a presença diária de um farmacêutico. Nos crimes de roubo e furto de carga, os remédios são um dos artigos preferidos dos criminosos. Assim, a impunidade não decorre do fato do art. 273 do CP estabelecer pena de um a três anos, ou, atualmente, pena de 10 a 15 anos. Com essa legislação irracional tornando tais crimes hediondos, haverá uma natural resistência dos juízes na sua aplicação, pois não adianta punir aqueles indivíduos que praticam a pequena fraude sem maiores consequências, sem que se rompa a estrutura maior de corrupção das quadrilhas especializadas, dos fiscais corruptos, da efetiva

\footnotetext{
${ }^{55}$ REALE JUNIOR, Miguel. A inconstitucionalidade da lei dos remédios. RT. São Paulo. a. 88. v. 763. p. 415, maio 1999.

56 BRASIL, Supremo Tribunal Federal. Voto do Ministro Luís Roberto Barroso. Disponível em http://www.luisrobertobarroso.com.br/wp-content/uploads/2016/10/RE-657718-Medicamentos-sem-regis tro-Anvisa-versão-final.pdf. Acesso em 28 nov. 2017. Transcrevemos: "o medicamento deve possuir registro junto a renomados órgãos ou agencias de regulação no exterior, tais como a "Food and Drug Administration" (FDA) dos EUA, a "European Agency for the Evaluation of Medicinal Products" (EMEA) da União Europeia, e a "Japanese Ministry of Health \& Welfare" do Japão. Nesses casos, a aprovação da droga (ainda não registrada no Brasil) em países que possuem sistemas de vigilância sanitária sérios e respeitados fora do pais mitiga os riscos à saúde envolvidos no seu fornecimento a pacientes por determinação judicial. É preciso, porém, ressalvar que se trata aqui de uma situação excepcional, justificada pela mora irrazoável e injustificada da Anvisa".
} 
punição dos comerciantes que vendem sem receita, da orientação social a respeito da desnecessidade de muitos medicamentos (os remédios para a gripe, por exemplo, combatem os efeitos e não a doença).

0 grave problema dos medicamentos falsificados possui um quadro bem mais complexo do que a mera alteração dos tipos penais que punem tais condutas. É a própria questão da saúde pública no Brasil que precisa ser discutida e alterada ${ }^{57}$.

Esses pontos nos levam a concluir que o legislador acabou por atribuir uma importância elevada demais ao ato administrativo do registro de medicamentos perante a Agência Reguladora, descurando, de um lado, dos mecanismos burocráticos da Anvisa que impedem o rápido e eficiente registro de medicamentos e demais substâncias medicinais e, de outro, da existência de outros instrumentos regulatórios de controle que podem ser tão ou mais eficazes quanto a autorização da Anvisa.

Nada impede, por exemplo, que a Agência autorize a produção e a comercialização de medicamentos não registrados junto à Anvisa, condicionando a sua venda à expressa autorização médica, tal qual ocorre hoje com as drogas sujeitas a controle especial - notadamente entorpecentes e substâncias psicotrópicas anorexígenas. No ponto, a Portaria Anvisa $n^{\circ} 344$, de 12 de maio de 1998, que aprovou o Regulamento Técnico sobre substâncias e medicamentos sujeitos a controle especial, estabeleceu, nos artigos 35 e seguintes, a possibilidade de venda de remédios controlados por meio da chamada "notificação de receita".

Os mesmos mecanismos de controle de substâncias e medicamentos controlados poderiam ser adotados para substâncias e medicamentos sem registro, mas não proscritos, afastando, portanto, a incidência do inciso I do $\S 1^{\circ}$-B do artigo 273 do Código Penal. 0 próprio Superior Tribunal de Justiça, ultrapassando as dificuldades regulatórias, e sobrepujando a norma penal, tem entendido que a prescrição médica constitui prova bastante para a impetração de mandado de segurança voltado a garantir o fornecimento de medicamentos não registrados perante a Anvisa ${ }^{58}$. Ou seja, atribuiu a Corte relevância maior ao laudo médico e menor ao registro em sede administrativa. Trata-se de uma questão eminentemente regulatória, decorrente da ineficiência do registro para a proteção da saúde pública, o que, por si só, sugere a revisão do modelo e, em especial, da interpretação dada a esse tipo penal.

Não se pretende, aqui, propor um novo modelo de controle de substâncias e medicamentos não registrados, tampouco esgotar saídas regulatórias para um melhor controle dos medicamentos pela Anvisa, mas, apenas, evidenciar que a simples possibilidade de fabricação ou

\footnotetext{
${ }^{57}$ FARIA, Antônio Celso Campos de Oliveira. A vulgarização do crime hediondo. IBCCRIM. Boletim $n^{\circ} 71$, de Outubro de 1998.

58 BRASIL. Superior Tribunal de Justiça. AgInt no AREsp 405.126/DF, Primeira Turma, Rel. Ministro Gurgel de Faria, julgado em 20/09/2016.
} 
importação, e a comercialização de medicamento sem registro não implica colocar à disposição do público um remédio ou substância potencialmente danosos a ponto de justificar a criminalização tal como prevista pela "Lei dos Remédios", em especial em um setor onde se destacam as falhas regulatórias, a omissão e a mora da Anvisa, além do ativismo do Judiciário em buscar a aplicação da regra do artigo 196 da Constituição, com a liberação do fornecimento de medicamentos não registrados.

Há, a toda evidência, alternativas regulatórias e outros instrumentos de controle da produção, importação e comercialização de medicamentos que prescindem da tipificação penal como prima ratio e que têm melhor condição de garantir a proteção dos direitos individuais em jogo, resguardando mais adequadamente o bem jurídico saúde pública, inclusive em consonância com o artigo 196 da Constituição.

A necessidade de aperfeiçoamento do sistema regulatório justifica a adoção de uma interpretação da regra contida no inciso I do $\S 1^{\circ}$-B do artigo 273 do Código Penal de modo a afastar a presunção estabelecida pelo legislador e autorizar a não aplicação do tipo penal quando não houver comprovação do potencial de dano em razão da venda dos medicamentos não registrados na Anvisa.

A solução parece estar, assim, em dar interpretação conforme à norma penal contida no inciso I do $\S 1^{\circ}$-B do artigo 273 do Código Penal, para exigir a comprovação de prejuízo ou de efetiva potencialidade de dano advinda da comercialização de medicamentos e demais substâncias medicinais ou terapêuticas quando esses produtos não estiverem listados como nocivos à saúde no âmbito da Agência Nacional de Vigilância Sanitária.

Em outras palavras, nos casos em que não houver o registro, o perigo deve ser concreto, e a persecutio criminis deve ficar condicionada à comprovação, por parte da acusação, da premissa estabelecida pelo legislador para a aplicação do tipo penal, qual seja, a ameaça de dano à saúde pública. A prévia aprovação médica, assim como a aprovação da comunidade científica ou mesmo de renomadas agências reguladoras estrangeiras, como a FDA, a MNE e PMDA, já previamente citadas, devem ser suficientes para obstaculizar a persecutio criminis, que dependerá da prova da efetiva potencialidade de dano, a ser examinada caso a caso. 


\section{CONCLUSÃO}

Tratou-se, neste artigo, da contradição existente entre o posicionamento dos Tribunais Superiores quanto às constitucionalidade e legalidade da regra insculpida no inciso I do $\S 1^{\circ}$-B do artigo 273 do Código Penal, voltado a proteger a saúde pública, e as decisões proferidas pelos mesmos Tribunais Superiores no sentido de autorizar o fornecimento de medicamentos não registrados junto à Anvisa, também com o escopo de garantir a tutela da saúde dos cidadãos pelo Estado, porém, à luz do artigo 196 da Constituição.

Embora os Tribunais Superiores tenham ratificado o seu posicionamento quanto à constitucionalidade do tipo penal e do enquadramento da hipótese de fornecimento de medicamentos sem registro na Anvisa como um instrumento essencial para a proteção do bem jurídico saúde pública, esses mesmos Tribunais adotam uma postura contraditória ao autorizar o fornecimento de medicamentos não registrados junto à Agência Reguladora, ao argumento de que o Estado não pode ferir a autonomia dos cidadãos, mas deve assegurar o acesso universal e igualitário às ações e serviços para a promoção, proteção e recuperação da saúde.

Essa contradição evidencia, em primeiro lugar, a falta de proporcionalidade da regra penal estabelecida no inciso I do $\S 1^{\circ}$-B do artigo 273 do Código Penal, no que ela prevê punição para uma conduta que não necessariamente é prejudicial à saúde. A falta de proporcionalidade atrai, por sua vez, a necessidade da relativização da norma, com a adoção de interpretação conforme à Constituição, para retirar o caráter de perigo abstrato e permitir o afastamento da norma penal quando não houver a comprovação dos riscos e dos prejuízos.

A comercialização de medicamentos sem registro não pode, por si só, ser enquadrada como um crime de perigo abstrato, seja porque essa medida implica em prejuízo desproporcional aos direitos individuais em jogo, seja porque há a possiblidade da adoção de medidas menos gravosas para buscar a proteção dos direitos relacionados à saúde. É possível à Agência Reguladora impor limitações administrativas que não vedem por completo a produção, importação e comercialização de medicamentos e congêneres que não contenham registro junto à Anvisa, sem que seja necessário adotar a persecução penal como prima ratio.

Apenas as hipóteses em que a Anvisa já tenha expressa e fundamentadamente vedado determinado produto ou substância em razão de serem comprovadamente nocivos à saúde é que parece possível falar em um risco efetivo e concreto de prejuízo aos consumidores, a fim de justificar a adoção da persecutio criminis. As demais hipóteses, em especial aquelas em que a Agência está em mora na apreciação do pedido de registro, exigem a interpretação da regra estabelecida ao inciso I do $§ 1^{\circ}$-B do artigo 273 do Código Penal, para condicionar a adoção e a 
aplicação do direito penal à comprovação, pela acusação, do risco de prejuízo à saúde pública, inclusive à vista do entendimento do Judiciário e dos Tribunais Superiores, que autorizam, eles próprios, o fornecimento de medicamentos não registrados na Anvisa, a fim de dar cumprimento à regra do artigo 196 da Constituição.

A solução mais adequada para encontrar o equilíbrio entre a proteção do bem jurídico saúde pública à luz do interesse coletivo e dos interesses individuais está no aperfeiçoamento dos instrumentos regulatórios e não na intensificação das regras de direito penal.

\section{REFERÊNCIAS}

AGUADO CORREA, Teresa. El principio de proporcionalidad en Derecho Penal. Madrid: Edersa; 1999 , p. 394.

BOTTINI, Pierpaolo Cruz. In Crimes de Perigo Abstrato e Princípio da Precaução na Sociedade de Risco, São Paulo: Revistas dos Tribunais. 2007. p. 120/121.

BOTTINI, Pierpaolo. Crimes de Perigo Abstrato e Princípio da Precaução na Sociedade de Risco, São Paulo: Revistas dos Tribunais. 2007. p. 231/232.

BRASIL, Decreto n².848, de 7 de dezembro de 1940. Institui o Código Penal. In: Diário Oficial da República Federativa do Brasil, Brasília, DF, 31 dez. 1940. Disponível em http://www.planalto.gov.br, artigo 273. Acesso em 8 mai. 2018.

BRASIL, Lei $n^{\circ}$ 6.360, de 23 de setembro de 1976, que Dispõe sobre a Vigilância Sanitária a que ficam sujeitos os Medicamentos, as Drogas, os Insumos Farmacêuticos e Correlatos, Cosméticos, Saneantes e Outros Produtos. In: Diário Oficial da República Federativa do Brasil, Brasília, DF, 24 set. 1976. Disponível em

http://www.planalto.gov.br/ccivil_03/leis/l6360.htm?TSPD_101_R0=827811d9dba6b3420f0cdafd 692d9c14a190000000000000000ae8a3cbdffff00000000000000000000000000005af1b38d00a8b5ba7 $\underline{8}$ Acesso em 8 mai. 2018.

BRASIL, Lei $\mathrm{n}^{\circ} 11.343$, de 23 de agosto de 2006. Dispõe sobre o Sistema Nacional de Políticas Públicas sobre Drogas - Sisnad; prescreve medidas para prevenção do uso indevido, atenção e reinserção social de usuários e dependentes de drogas; estabelece normas para repressão à produção não autorizada e ao tráfico ilícito de drogas; define crimes e dá outras providências. In: Diário Oficial da República Federativa do Brasil, Brasília, DF, 24 ago. 2006. Disponível em http://www.planalto.gov.br/ccivil_03/_ato2004-2006/2006/lei//11343.htm Acesso em 8 mai. 2018.

BRASIL, Lei $n^{\circ}$ 6.437, de 20 de agosto de 1977. Configura infrações à legislação sanitária federal e estabelece as sanções respectivas, e dá outras providências. In: Diário Oficial da República Federativa do Brasil, Brasília, DF, 24 ago. 1977. Disponível em http: //www.planalto.gov.br/ccivil_03/leis/l6437.htm?TSPD_101_R0=1c6de2098e2f3f605c0957c2 f3aa1a71c5C0000000000000000ae8a3cbdffff00000000000000000000000000005af11f6b00ef33db7e Acesso em 8 mai. 2018. 
BRASIL, Lei $n^{\circ}$ 9.782, de 26 de janeiro de 1999. Dispõe sobre o Sistema Nacional de Vigilância Sanitária, cria a Agência Nacional de Vigilância Sanitária, e dá outras providências. In: Diário Oficial da República Federativa do Brasil, Brasília, DF, 27 jan. 1999. Disponível em http://www.planalto.gov.br/ccivil_03/leis//9782.htm?TSPD_101_R0=4ac3c8e7fdac0120ab1441ac be46b55dlD60000000000000000ae8a3cbdffff00000000000000000000000000005af12be900f13ac244 Acesso em 8 mai. 2018.

Brasil, Projeto de Lei n 4535, de 21 de maio de 1998. Disponível em: http: / /www.camara.gov.br/proposicoesWeb/fichadetramitacao?idProposicao=25675. Acesso em 25 out. 2017.

BRASIL, Senado Federal. Informação do Senado-Notícias. Disponível em https://www12.senado.leg.br/noticias/materias/2016/03/09/necessidade-de-agilizar-registrode-medicamentos-e-consenso-em-debate-na-cas Acesso em 8 mai. 2018.

BRASIL, Supremo Tribunal Federal, Decisão Monocrática do Ministro Marco Aurélio no processo $\mathrm{n}^{\circ}$ 657.718/MG. Disponível em:

http://www.stf.jus.br/portal/jurisprudenciaRepercussao/verPronunciamento.asp?pronunciamen to=3815705\&tip=manifestacao Acesso em 8 mai. 2018.

BRASIL, Supremo Tribunal Federal. ADI 5501 MC, Relator Min. MARCO AURÉLIO, Tribunal Pleno, julgado em 19/05/2016, DJe-168 PUBLIC 01-08-2017. Disponível em http: / / portal.stf.jus.br/processos/downloadPeca.asp?id=312214682\&ext=.pdf Acesso em 8 mai. 2018.

BRASIL, Supremo Tribunal Federal. Suspensão de Segurança $n^{\circ} 4.316 / R O$, Relator Ministro Presidente Cezar Peluso, apreciado em 7 de junho de 2011. Decisão disponível em http: //stf.jus.br/portal/processo/verProcessoTexto.asp?id=3000680\&tipoApp=RTF Acesso em 8 mai. 2018.

BRASIL, Supremo Tribunal Federal. Suspensão de Segurança $n^{\circ}$ 5.192/RO, Relatora Ministra Presidente Carmén Lúcia, apreciado em 16 de agosto de 2017. Decisão disponível em http://stf.jus.br/portal/processo/verProcessoPeca.asp?id=312439101\&tipoApp=.pdf Acesso em 8 mai. 2018.

BRASIL, Supremo Tribunal Federal. Voto do Ministro Luís Roberto Barroso. Disponível em http: / / www.luisrobertobarroso.com.br/wp-content/uploads/2016/10/RE-657718-Medicamentossem-regis tro-Anvisa-versão-final.pdf. Acesso em 28 nov. 2017.

BRASIL, Tribunal de Contas da União. Relatório de Auditoria do Tribunal de Contas da União $\mathrm{n}^{\circ}$ 009.253/2015-7, Ministério da Saúde, de Relatoria do Ministro Bruno Dantas. Disponível em: https: / / contas.tcu.gov.br/etcu/AcompanharProcesso?p1=9253\&p2=2015\&p3=7. Acesso em 20 out. 2017.

BRASIL, Tribunal de Justiça de São Paulo. Ementa do acórdão de n 9140356-92.2000.8.26.0000 (993.00.099021-0).

BRASIL. ANVISA. Portaria ${ }^{\circ} 344$, de 12 de maio de 1998. Aprovou o Regulamento Técnico sobre substâncias e medicamentos sujeitos a controle especial. In: Diário Oficial da República 
Federativa do Brasil, Brasília, DF, 31 dez. 1998. Disponível em:

http://www4.anvisa.gov.br/base/visadoc/port/port[939-2-0].htm . Acesso em 28 out. 2017.

BRASIL. Superior Tribunal de Justiça, HC 239.363/PR, Rel. Ministro SEBASTIÃO REIS JÚNIOR, SEXTA TURMA, julgado em 19/11/2012, DJe 18/12/2012. Disponível em

https://ww2.stj.jus.br/processo/revista/inteiroteor/?num_registro=201200764901\&dt_publicaca $\mathrm{o}=18 / 12 / 2012$ Acesso em 8 mai. 2018.

BRASIL. Superior Tribunal de Justiça. AgInt no AREsp 405.126/DF, Primeira Turma, Rel. Ministro Gurgel de Faria, julgado em 20/09/2016. Disponível em

http: / / www.stj.jus.br/SCON/jurisprudencia/doc.jsp?livre=405126\&b=ACOR\&p=true\&l=10\&i=3 Acesso em 8 mai. 2018.

BRASIL. Supremo Tribunal Federal, RE n 829226 AgR, Relator Min. Luiz Fux, Primeira Turma, julgado em 10/02/2015, DJe-043 Public 06/03/2015, Disponível em

http: //portal.stf.jus.br/processos/downloadTexto.asp?id=3745332\&ext=RTF Acesso em 8 mai.

2018.

BRASIL. Supremo Tribunal Federal, RE $n^{\circ} 971187$ AgR, Relator Min. Teori Zavascki, Segunda Turma, julgado em 07/10/2016, DJe-228 Public 26/10/2016 Disponível em

http://portal.stf.jus.br/processos/downloadPeca.asp?id=310595879\&ext=.pdf Acesso em 8 mai. 2018.

FARIA, Antônio Celso Campos de Oliveira. A vulgarização do crime hediondo. IBCC. Boletim $\mathrm{n}^{\circ}$ 71, de Outubro de 1998.

FRAGOSO, Heleno. Lições de Direito Penal, São Paulo: José Bushatsky Editor, 1959, v. 3, p. 701.

GRECO, Luís. Princípio da ofensividade e crimes de perigo abstrato - uma introdução ao debate sobre o bem jurídico e as estruturas do delito. Revista Brasileira de Ciências Criminais: RBCCrim, v. 12, n. 49, p. 89-147, jul./ago. 2004.

GUIMARÃES, Luís Paulo Cotrim. Penas descalibradas e leis nascidas do casuísmo exigem malabarismo de juízes. Revista Consultor Jurídico. 2014.

Informativo $\mathrm{n}^{\circ} 841$ do Supremo Tribunal Federal de 10 de outubro de 2016. Disponível em: http://www.stf.jus.br/arquivo/informativo/documento/informativo841.htm. Acesso em mai. 2018.

KOERNER, Andrei. Desordem Legislativa, Distribuição de Poder e Desigualdade Social Reflexões a Propósito da Lei $\mathrm{n}^{\circ} \mathbf{9 . 6 7 7}$, de 2 de Julho de 1998. INSTITUTO BRASILEIRO DE CIÊNCIAS CRIMINAIS - IBBCC, Boletim nº 71, de Outubro de 1998.

NASCIMENTO, Elisa Gattás Fernandes do. Contrafação de Medicamentos: uma análise sob a ótica da saúde pública. Ciências Penais | vol. 15/2011 | p. 105 - 132 | Jul - Dez / 2011. DTR\2011\5213.

NUCCI, Guilherme de Souza. Manual de Direito Penal. $7^{a}$ edição. São Paulo: Revista dos Tribunais. p. 944. 
PASCHOAL, Janaina Conceição. A falsificação de remédios, a combinação de normas e a importação de medicamento. IBCCRIM. Boletim - 234 - Maio /2012.

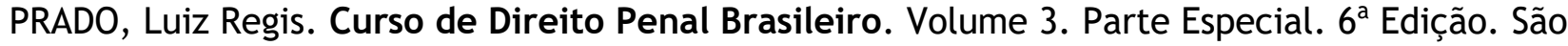
Paulo: Revista dos Tribunais. 2010. p. 139/140.

REALE JUNIOR, Miguel. A inconstitucionalidade da lei dos remédios. RT. São Paulo. a. 88. v. 763. p. 415, maio 1999.

ROXIN, Claus. Derecho Penal: Parte General, Tomo I, p. 407.

SILVA FRANCO, Alberto. Crimes Hediondos. 4ª Edição. São Paulo: Revistas dos Tribunais, 2000.

SILVEIRA, Renato de Mello Jorge. Novas Considerações Quanto à Proteção Penal da Saúde Pública, em Doutrinas Essenciais de Direito Penal Econômico e da Empresa. Vol. 3. Julho de 2011. p. $1185 / 1193$.

Recebido em: 11.05.2018 / Revisões requeridas em: 30.08.2018 / Aprovado em: 11.09.2018 / Publicado em: 01.01.2019

\section{COMO FAZER REFERÊNCIA AO ARTIGO (ABNT):}

BOTTINO, Tiago; SCHILLER, Alexandre Ortigão Sampaio Buarque. Aspectos penais e regulatórios da venda de medicamentos sem registro. Revista Eletrônica do Curso de Direito da UFSM, Santa Maria, RS, v. 14, n. 1, e32592, jan./abr. 2019. ISSN 1981-3694. Disponível em: < https://periodicos.ufsm.br/revistadireito/article/view/32592 >. Acesso em: dia mês. ano. doi: http://dx.doi.org/10.5902/1981369432592.

Direitos autorais 2019 Revista Eletrônica do Curso de Direito da UFSM

Editores responsáveis: Rafael Santos de Oliveira e Angela Araujo da Silveira Espindola

Este obra está licenciado com uma Licença Creative Commons Atribuição-NãoComercial-SemDerivações 4.0 Internacional.

\section{SOBRE OS AUTORES}

\section{THIAGO BOTTINO DO AMARAL}

Bacharel em Direito pela Universidade Federal do Estado do Rio de Janeiro (1999), Mestre (2004) e Doutor (2008) em Direito pela PUC-Rio. Pós-Doutor pela Columbia Law School (2014). Professor Visitante (short-term international visiting professor) na Columbia Law School (2018) Professor Adjunto e Coordenador do Curso de Graduação em Direito da FGV DIREITO RIO. Professor do Corpo Docente Permanente do Mestrado em Direito e Regulação. Professor Adjunto de Direito Penal e Processual Penal da Universidade Federal do Estado do Rio de Janeiro (UNIRIO). Pesquisador-Visitante do IPEA (2013-2015), coordenando projeto de Pesquisa sobre Habeas Corpus nos Tribunais Superiores em parceria com o Ministério da Justiça. Coordenou projeto de pesquisa sobre as medidas cautelares no Processo Penal em parceria com o Ministério da Justiça (2009-2010) e com financiamento do PNUD. Membro efetivo do Instituto dos Advogados Brasileiros (IAB) e integrante da Comissão Permanente de Direito Penal e da Comissão de Direitos Humanos. Integrou as Comissões de Direitos Humanos (2007), de Exame de Ordem (2007-2009) e de Estudos de Direito Penal (2014-2016) da OAB/RJ e a Comissão de Direito Constitucional do Conselho Federal da OAB (2015-2016). Atualmente integra o Observatório Jurídico da OAB/RJ para a Intervenção Federal. Associado ao IBCCRIM, tendo exercido as funções de Vice-Presidente (2017-2018), Diretor do Departamento de Amicus Curiae (2013-2014) e Diretor de Projetos Legislativos (20192020), além de ter integrado a Comissão Organizadora do Seminário Internacional (2015-2016, 2017-2018, 2019-2020) e o departamento de Amicus Curiae (2012-2020).

\section{ALEXANDRE ORTIGÃO SAMPAIO BUARQUE SCHILLER}

Possui graduação em Direito pela Pontifícia Universidade Católica do Rio de Janeiro (2008). Atualmente é advogado - Paulo Cezar Pinheiro Carneiro Advogados Associados. Tem experiência na área de Direito, com ênfase em Direito Privado, atuando principalmente nos seguintes temas: direito civil, administrativo, regulatório, tributário e energia. 